\title{
The Unique 473HD-Chondroitinsulfate Epitope Is Expressed by Radial Glia and Involved in Neural Precursor Cell Proliferation
}

\author{
Alexander von Holst, ${ }^{\star}$ Swetlana Sirko, ${ }^{\star}$ and Andreas Faissner \\ Chair Cell Morphology and Molecular Neurobiology, Faculty of Biology, Ruhr-University Bochum, D-44780 Bochum, Germany
}

\begin{abstract}
Neural stem cells have been documented in both the developing and the mature adult CNSs of mammals. This cell population holds a considerable promise for therapeutical applications in a wide array of CNS diseases. Therefore, universally applicable strategies for the purification of this population to further its cell biological characterization are sought. Here, we report that the unique chondroitin sulfate epitope recognized by the monoclonal antibody 473HD is surface expressed on actively cycling, multipotent progenitor cells of the developing telencephalon with radial glia-like properties. When used for immunopanning, the antibody enriched at least threefold for neural stem/progenitor cells characterized by the ability to self-renew as neurospheres that generated all major neural lineages in differentiation assays. In contrast, the 473HD-depleted cell fraction was mostly devoid of neurosphere-forming cells. The isolation of 473HD-positive adult multipotent progenitors from the subependymal zone of the lateral ventricle wall revealed a substantial overlap with the known adult neural stem cell marker LewisX. When the chondroitin sulfates were removed from immunoselected 473HDpositive neural stem/progenitor cell surfaces by chondroitinase $\mathrm{ABC}$ treatment or perturbed by the monoclonal antibody $473 \mathrm{HD}$ that recognizes the unique DSD-1 chondroitin sulfate epitope, the generation of neurospheres was significantly reduced. Thus, the 473HD epitope could not only be used for the isolation of multipotent neural progenitors during forebrain development as well as from the adult neurogenic niche but may also constitute a functionally important entity of the neural stem cell niche.
\end{abstract}

Key words: monoclonal antibody; extracellular matrix; marker; neural precursor; neurogenesis; cell fate; gliogenesis; stem cells; subventricular zone

\section{Introduction}

During the early phase of forebrain development, neuroepithelial cells expand by cycles of symmetric divisions (Temple, 2001). Subsequently, these cells give rise to radial glia cells that divide asymmetrically during neurogenesis, yielding a postmitotic neuronal precursor cell and a daughter cell that re-enters the cell cycle (Temple, 2001; Wodarz and Huttner, 2003). Radial glia cells, beyond their well known function as scaffold and guides for neuronal migration (Sidman and Rakic, 1973), do give rise to neurons in vitro (Malatesta et al., 2000; Hartfuss et al., 2001) and act as neuronal progenitors in vivo, as shown by fate-mapping studies (Miyata et al., 2001; Noctor et al., 2001, 2002; Malatesta et al., 2003; Anthony et al., 2004). The immunocytochemical analysis of radial glia with the marker molecules RC2 (Chanas-Sacre

\footnotetext{
Received 0ct. 7, 2005; revised March 3, 2006; accepted March 7, 2006.

This work was supported by the German Research Council (Deutsche Forschungsgemeinschaft, SPP 1109, vHo 2476/1-3). We thank Dr. N. Heintz (Rockefeller Institute, New York, NY) for the gift of anti-BLBP antibodies and Dr. D. Pow (University of Queensland, Brisbane, Australia) for the gift of anti-GLAST antibodies. The RC2 antibody was made available from the Developmental Studies Hybridoma Bank (University of lowa, lowa City, IA). We thank M. Götz for helpful comments on this manuscript. We are indebted to the excellent technical support of Anke Baar. A.v.H. and S.S. contributed equally to this work.

Correspondence should be addressed to Prof. Andreas Faissner, Chair Cell Morphology and Molecular Neurobiology, Faculty of Biology, Ruhr-University Bochum, NDEF 05/594, Universitätsstrasse 150, D-44780 Bochum, Germany. E-mail: andreas.faissner@ruhr-uni-bochum.de.

D01:10.1523/JNEUROSCI.0422-06.2006

Copyright $\odot 2006$ Society for Neuroscience $\quad$ 0270-6474/06/264082-13\$15.00/0
}

et al., 2000), GLAST (Shibata et al., 1997), and BLBP (Feng et al., 1994) has revealed several subpopulations that change dynamically during telencephalic development (Hartfuss et al., 2001). The radial glia cells transform into astrocytes around birth and a specialized subpopulation, the subventricular zone (SVZ) astrocyte, that has been identified as a neural stem cell (NSC) in the adult brain (Doetsch et al., 1999). It has been hypothesized that neuroepithelial cells, radial glia cells, and SVZ astrocytes constitute the NSC lineage (Alvarez-Buylla et al., 2001; Doetsch, 2003). Several reports have described the isolation of NSCs from postnatal or adult forebrain (Rietze et al., 2001; Capela and Temple, 2002; Belachew et al., 2003; Kim and Morshead, 2003). These studies reported significant advances based on fluorescenceactivated cell-sorter (FACS) techniques using a lectin-negative cell-surface marker exclusion protocol (Rietze et al., 2001), antibodies against LewisX (LeX) (Capela and Temple, 2002), or cells selected from the brain of CNP-GFP transgenic mice (Belachew et al., 2003). In vitro, the NSC fraction was enriched from adult neurospheres using a dye exclusion paradigm or LeX (Capela and Temple, 2002; Kim and Morshead, 2003). In situ, NSCs are located in a niche that consists of a restricted set of cell types and contains a specialized microenvironment composed of soluble factors, membrane-bound molecules, and extracellular matrix constituents (Alvarez-Buylla and Lim, 2004). One extracellular matrix component present in the postnatal and adult NSC niche 
is the DSD-1-proteoglycan, which is selectively recognized by the monoclonal antibody (mAb) 473HD (Faissner et al., 1994; Gates et al., 1995). Therefore, it seemed promising to investigate whether the 473HD epitope is present on NSC surfaces. Here, we show that the 473HD epitope is expressed in the germinal layers of the telencephalon during development and in the adult SVZ of the lateral ventricle wall and report the immunoisolation of 473HD-positive cells. The cell biological characterization suggests that the DSD-1 epitope is a surface marker of a subpopulation of neurogenic radial glia with NSC properties. In addition, interference with chondroitin sulfates on the surface of 473HDpositive cells revealed that this class of glycosaminoglycans is involved in the pathway of neurosphere generation.

\section{Materials and Methods}

Animals. All experiments in this study were performed with embryos derived from timed pregnancies of the NMRI mouse strain (Charles River Laboratories, Sulzfeld, Germany). The age of the embryos was determined according to the staging criteria of Theiler, in which embryonic day 13 (E13) corresponds to Theiler stage 21 (Bard et al., 1998).

Immunological reagents. The following primary antibodies were used in this study. The monoclonal antibodies were as follows: 473HD (rat IgM) (Faissner et al., 1994), 487 (L5 epitope/LeX, rat IgM) (Streit et al., 1996), RC2 (mouse IgM; Developmental Studies Hybridoma Bank, University of Iowa, Iowa City, IA), O4 (mouse IgM) (Sommer and Schachner, 1981), polysialic-acid-containing neural cell adhesion molecule (PSA-NCAM) (Rougon et al., 1986), anti-nestin (mouse IgG; Chemicon, Temecula, CA), anti- $\beta$ III-tubulin (mouse IgG; Sigma, St. Louis, MO), and anti-5-bromo-2-deoxyuridine (BrdU) (mouse IgG; Roche Products, Welwyn Garden City, UK). The polyclonal antibodies (all rabbit) were against the following: DSD-1-PG/phosphacan [referred to as pk-anti-phosphacan, batch KAF 13(4)] (Faissner et al., 1994), GFAP (Dako, High Wycombe, UK), NG2 (Chemicon), brain lipid-binding protein (BLBP; gift from Dr. N. Heintz, Rockefeller University, New York, NY), and GLAST (gift from Dr. D. Pow, University of Queensland, Brisbane, Australia; or Chemicon). The secondary antibodies were as follows: subclass-specific biotinylated and CY2- or CY3-coupled antimouse, anti-rat, and anti-rabbit antibodies (all from Dianova, Hamburg, Germany). We used streptavidin-AlexaFluor350 (Invitrogen, San Diego, CA) to reveal biotinylated reagents.

Immunohistochemistry. Pregnant animals were killed by cervical dislocation. The embryos were removed and transferred to PBS (in mM: 137 $\mathrm{NaCl}, 3 \mathrm{KCl}, 6.5 \mathrm{Na}_{2} \mathrm{HPO}_{4} \cdot 2 \mathrm{H}_{2} \mathrm{O}$, and $1.5 \mathrm{KH}_{2} \mathrm{PO}_{4}, \mathrm{pH}$ 7.4). Subsequently, the brains were prepared and immersion fixed overnight with $4 \% \mathrm{w} / \mathrm{v}$ paraformaldehyde (PFA) in PBS at $4^{\circ} \mathrm{C}$. Thereafter, tissues were cryoprotected overnight with $30 \% \mathrm{w} / \mathrm{v}$ sucrose in $\mathrm{H}_{2} \mathrm{O}$, embedded in tissue-freezing medium (Jung, Nussloch, Germany), and frozen on dry ice. Sections $(12-14 \mu \mathrm{m})$ were cut on a cryostat (Leica, Nussloch, Germany). For immunohistochemistry on frontal sections, slides were rehydrated in PBS with $1.7 \% \mathrm{w} / \mathrm{v} \mathrm{NaCl}$ and $10 \% \mathrm{v} / \mathrm{v}$ normal goat serum (Dianova) for $1 \mathrm{~h}$ at room temperature before incubation with the following primary antibodies: 473HD (1:500), RC2 (1:500), anti-nestin (1: $500)$, anti- $\beta$ III-tubulin (1:300), anti-BLBP (1:1000-2000), anti-NG2 (1: $200)$, and anti-GLAST (1:1500). The sections were incubated with primary antibodies diluted in PBS, $1.7 \% \mathrm{w} / \mathrm{v} \mathrm{NaCl}, 10 \% \mathrm{v} / \mathrm{v}$ normal goat serum, and $0.1 \%$ Triton $\mathrm{X}-100$ overnight at $4^{\circ} \mathrm{C}$. Subsequently, the sections were washed three times for $5 \mathrm{~min}$ in PBS and incubated with adequate secondary antibodies diluted 1:500 in PBS/A [PBS containing $0.1 \% \mathrm{w} / \mathrm{v}$ bovine serum albumin (BSA; Sigma)] for $2 \mathrm{~h}$ at room temperature. During incubation with secondary antibodies, cell nuclei were labeled with bisbenzimide (diluted 1:10 ${ }^{5}$; Sigma). After three additional washes in PBS, the sections were mounted in Immumount (Thermo Electron, Dreieich, Germany).

Immunocytochemistry of acutely dissociated cells. Embryos at E13 or E18 were removed as described above. Embryonic brains were dissected and transferred to minimal essential medium (MEM; Sigma). The meninges, hippocampi, and olfactory bulbs were removed, and the cerebral cortices and the ganglionic eminence (GE) were isolated. Tissues were enzymatically digested with $0.05 \%$ trypsin-EDTA in HBSS (Invitrogen) for 10 or $20 \mathrm{~min}$ at $37^{\circ} \mathrm{C}$ to obtain E13 and E18 embryonic cell suspensions, respectively. The enzyme activity was stopped by the addition of 1 $\mathrm{ml}$ of ovomucoid [ $1 \mathrm{mg} / \mathrm{ml}$ soybean trypsin inhibitor (Sigma), $50 \mu \mathrm{g} / \mathrm{ml}$ BSA, and $40 \mu \mathrm{g} / \mathrm{ml}$ DNaseI (Worthington, Freehold, NJ) in L-15 medium (Sigma)]. After centrifugation for $5 \mathrm{~min}$ at $1000 \mathrm{rpm}(212 \mathrm{~g})$, the cell pellets were resuspended in neurosphere medium consisting of DMEM/F-12 (1:1) containing $0.2 \mathrm{mg} / \mathrm{ml} \mathrm{L-glutamine} \mathrm{(all} \mathrm{from} \mathrm{Sigma);}$ and $2 \% \mathrm{v} / \mathrm{v}$ B27, $100 \mathrm{U} / \mathrm{ml}$ penicillin, and $100 \mu \mathrm{g} / \mathrm{ml}$ streptomycin (all from Invitrogen). Four-well dishes (Greiner, Kremsmünster, Austria) were sequentially coated with $10 \mu \mathrm{g} / \mathrm{ml}$ poly-ornithine (Sigma) in $\mathrm{H}_{2} \mathrm{O}$, followed by $10 \mu \mathrm{g} / \mathrm{ml} \mathrm{laminin-1} \mathrm{(Tebu,} \mathrm{Offenbach,} \mathrm{Germany)} \mathrm{in} \mathrm{PBS} \mathrm{for}$ $1 \mathrm{~h}$ at $37^{\circ} \mathrm{C}$ each. After the dishes were washed, the cells were plated at a density of 5000 cells/well in neurosphere medium containing $1 \% \mathrm{v} / \mathrm{v}$ FCS (Seromed, Berlin, Germany) and incubated in a humidified atmosphere with $6 \% \mathrm{v} / \mathrm{v} \mathrm{CO}_{2}$ at $37^{\circ} \mathrm{C}$. For immunocytochemical stainings, an established protocol was followed as described previously (von Holst and Rohrer, 1998). All steps were performed at room temperature. Acutely dissociated cells, adherent after $2 \mathrm{~h}$, were washed twice for $5 \mathrm{~min}$ in Krebs' solution-Ringer's solution-HEPES buffer (KRH/A; $125 \mathrm{~mm} \mathrm{NaCl}, 4.8$ $\mathrm{mm} \mathrm{KCl}, 1.3 \mathrm{~mm} \mathrm{CaCl} \cdot 2 \mathrm{H}_{2} \mathrm{O}, 1.2 \mathrm{~mm} \mathrm{MgSO}_{4} \cdot 7 \mathrm{H}_{2} \mathrm{O}, 1.2 \mathrm{~mm} \mathrm{KH}_{2} \mathrm{PO}_{4}$, $5.6 \mathrm{~mm}$ D-glucose, $25 \mathrm{~mm}$ HEPES, and $0.1 \% \mathrm{w} / \mathrm{v} \mathrm{BSA}$ ) and incubated for $20 \mathrm{~min}$ with the following antibodies against cell-surface/extracellular epitopes: 473HD (1:250), O4 (1:25), 487/LeX (1:250), or NG2 (1:200) all diluted in KRH/A. After washing twice for $5 \mathrm{~min}$ in $\mathrm{KRH}$, the cells were fixed with $4 \% \mathrm{w} / \mathrm{v}$ PFA in PBS for $10 \mathrm{~min}$, washed twice with PBT1 (PBS containing $1 \% \mathrm{w} / \mathrm{v}$ BSA and $0.1 \% \mathrm{w} / \mathrm{v}$ Triton X-100), and incubated for 30 min with antibodies against the intracellular epitopes RC2 (1:500), nestin (1:1000), $\beta$ III-tubulin (1:300), BLBP (1:1000), GLAST (1:2000), and GFAP (1:250), all diluted in PBT1. After three additional washes with $\mathrm{PBS} / \mathrm{A}$, the cells were incubated for $30 \mathrm{~min}$ with specific fluorochromelabeled secondary antibodies to detect the various primary antibodies. The last incubation step included bisbenzimide $\left(1: 10^{5}\right)$ to label cell nuclei. After a final washing in PBS, the objects were mounted in PBS/ glycerol (1:1) and viewed under an Axiophot II (Zeiss, Oberkochen, Germany) using UV-epifluorescence. To assay differentiated cell types in cultures of acutely dissociated or selectively isolated cortical and striatal cells, the same immunostaining protocol was performed after various time points.

Immunopanning and immunoisolation using magnetic beads (EasySep). To obtain 473HD epitope-expressing cortical and striatal cells using the $\mathrm{mAb} 473 \mathrm{HD}$, an immunopanning protocol was established, based on previous experience (von Holst and Rohrer, 1998). Two Petri dishes ( $100 \mathrm{~mm}$; Falcon) were incubated overnight at $4^{\circ} \mathrm{C}$ with $10 \mathrm{ml}$ of $50 \mathrm{~mm}$ Tris- $\mathrm{HCl}, \mathrm{pH} 9.5$, containing $50 \mu \mathrm{g} / \mathrm{ml}$ biotin-SP-conjugated, affinitypurified $\mathrm{F}\left(\mathrm{ab}^{\prime}\right) 2$ goat anti-rat IgM antibody fragments ( $\mu$ chain specific; Dianova). Afterward, the dishes were washed three times with PBS and incubated with the mAb 473HD $(2.6 \mu \mathrm{g} / \mathrm{ml})$ in PBS and $0.2 \% \mathrm{w} / \mathrm{v}$ BSA for at least $2 \mathrm{~h}$. Then, the panning dishes were washed three times with PBS. After enzymatic digestion of cortical or GE tissue with $0.05 \% \mathrm{w} / \mathrm{v}$ trypsin-EDTA in HBSS, the dissociated cell suspensions were allowed to recover for $1 \mathrm{~h}$ at $37^{\circ} \mathrm{C}$. Subsequently, $1.6 \times 10^{6}$ cells from the recovered cell suspensions were incubated per panning dish in $8 \mathrm{ml}$ of MEM and $0.2 \% \mathrm{w} / \mathrm{v}$ BSA for $1 \mathrm{~h}$ at room temperature. The nonadherent cells were gently washed away from the panning dish by five cycles of exposure to 8 $\mathrm{ml}$ of MEM at room temperature. The successful removal of nonadherent cells was monitored on an inverted microscope (Leica). If necessary, the washing cycles were repeated until only adherent cells remained. The latter were then recovered from the panning dish by incubation with $5 \mathrm{ml}$ of trypsin-EDTA in HBSS for $5 \mathrm{~min}$ at $37^{\circ} \mathrm{C}$. The resulting suspension was transferred to $8 \mathrm{ml}$ of MEM and 10\% v/v FCS and centrifuged for 5 $\mathrm{min}$ at $1000 \mathrm{rpm}$ at room temperature. The resulting pellet was resuspended in serum-free neurosphere medium (see above). In general, between 30 and $50 \%$ of the $473 \mathrm{HD}$-positive cells could be recovered, which corresponds to $3.2-5.4 \times 10^{4}$ cells at E18. Alternatively, we selected the $473 \mathrm{HD}$-positive cells with an immunoisolation procedure using paramagnetic beads (EasySep biotin selection kit) according to the manufacturer's instructions (CellSystem Biotechnology Vertrieb, St. Katharinen, 
Germany). For this purpose, E13 forebrain single-cell suspensions, obtained as described above, were incubated in $2 \mathrm{ml}$ of MEM and $0.2 \%$ BSA for $60 \mathrm{~min}$ at room temperature, followed by immunolabeling of the cells in suspension. We followed the procedure outlined above for staining of acutely dissociated cells, with the difference that, between each step of the protocol, the cell suspension was pelleted by centrifugation for $5 \mathrm{~min}$ at $1000 \mathrm{rpm}$. In short, the cell suspension was washed for $10 \mathrm{~min}$ in $\mathrm{KRH} / \mathrm{A}$, incubated with the $\mathrm{mAb}$ 473HD (1:200 in KRH/A) for $20 \mathrm{~min}$, and washed again for $10 \mathrm{~min}$ in $\mathrm{KRH} / \mathrm{A}$. After incubation with the biotinylated anti-rat IgM (1:300 in KRH/A) for $20 \mathrm{~min}$ and a washing step in $\mathrm{PBS} / \mathrm{A}$, the cell pellet was resuspended in PBS/A and transferred to a $5 \mathrm{ml}$ FACS tube (Falcon). The EasySep biotin selection mixture $(100 \mu \mathrm{l} / \mathrm{ml})$ was added for $15 \mathrm{~min}$, followed by the addition of EasySep magnetic nanoparticles $(50 \mu \mathrm{l} / \mathrm{ml})$ for an additional $10 \mathrm{~min}$ of incubation. This suspension was placed into the EasySep magnet for $10 \mathrm{~min}$. The supernatant containing the negative cell population was poured off, and $2 \mathrm{ml}$ of PBS/A was added twice for washing. Thereafter, the FACS tube was removed from the magnet, and the $473 \mathrm{HD}$-positive cell population was recovered by resuspending the cells in neurosphere medium. The purity and the degree of enrichment of the selectively isolated cell population were determined by immunocytochemistry $2 \mathrm{~h}$ after immunoselection, as described above.

Neurosphere cultures and sectioning for immunocytochemistry. Dissected tissues from the cerebral cortex and the GEs were acutely dissociated as described above. Embryonic NSCs as well as cells selectively isolated by immunopanning were cultured at $37^{\circ} \mathrm{C}$ in $6 \% \mathrm{CO}_{2}$ at a cell density of $10^{5}$ cells $/ \mathrm{ml}$ in T25 flasks (bulk culture) in serum-free neurosphere medium (see above) in the presence of epidermal growth factor (EGF) and basic fibroblast growth factor (bFGF), both at $20 \mathrm{ng} / \mathrm{ml}$ (Preprotech; Tebu), unless indicated otherwise. In general, bFGF-containing cultures were supplemented with $0.5 \mathrm{U} / \mathrm{ml}$ heparin (Sigma). Alternatively, the various single-cell suspensions were assayed for neurosphere formation in clonal density assays as described previously (Garcion et al., 2004). For the antibody perturbation experiments, the mAb $473 \mathrm{HD}$ and the isotype control $487 / \mathrm{LeX}$ were added once at a final concentration of $2.6 \mu \mathrm{g} / \mathrm{ml}$, when the cultures were set up. Under all conditions, the formation of neurospheres was monitored by inspection of the cultures on the stage of an inverted microscope (Leica) and quantified after $7 \mathrm{~d}$ in vitro (div) by counting the entire dish area (clonal density assays) or 10 randomly selected visual fields (bulk cultures). For differentiation assays, individual neurospheres of 200-250 $\mu \mathrm{m}$ diameter were transferred onto poly-ornithine/laminin-1-coated wells (coating was done sequentially for $1 \mathrm{~h}$ at $37^{\circ} \mathrm{C}$ at a concentration of $10 \mu \mathrm{g} / \mathrm{ml}$ for both substrates) and incubated in neurosphere medium (see above) with $1 \% \mathrm{v} / \mathrm{v} \mathrm{FCS}$ at $37^{\circ} \mathrm{C}$ and $6 \% \mathrm{v} / \mathrm{v} \mathrm{CO}_{2}$ for an additional $5 \mathrm{~d}$. The differentiated cell types were identified by immunocytochemistry using antibody markers described above. For cryosectioning, the neurospheres were allowed to settle in 15 $\mathrm{ml}$ Falcon tubes for $10 \mathrm{~min}$ before the culture medium was removed and replaced with $4 \% \mathrm{w} / \mathrm{v}$ PFA in PBS for $40 \mathrm{~min}$ at room temperature. After fixation, the neurospheres were cryoprotected with $30 \% \mathrm{w} / \mathrm{v}$ sucrose for $4 \mathrm{~h}$ at $4^{\circ} \mathrm{C}$. Finally, the neurospheres were embedded in tissue-freezing medium (Jung), sectioned at $14 \mu \mathrm{m}$ on a Leica cryostat, and processed for immunohistochemistry as described for embryonic brain sections.

$B r d U$ pulse labeling. In vivo labeling of cycling cells was performed by intraperitoneal injection of $10 \mathrm{mg}$ of BrdU (Sigma) per $100 \mathrm{~g}$ body weight 1 or $2 \mathrm{~h}$ before removal of the litter. The number of cells that incorporated BrdU was determined by immunocytochemical staining of acutely dissociated cells $2 \mathrm{~h}$ after plating (see above) according to the supplier's protocol (BrdU Labeling and Detection Kit I; Roche Products). For immunohistochemical detection of BrdU-positive cells in vivo, cryosections were boiled for $5 \mathrm{~min}$ in $0.01 \mathrm{M}$ citrate buffer, $\mathrm{pH}$ 6.0, followed by three washes in PBS before the incubation with the anti-BrdU mAb (1:20) at $4^{\circ} \mathrm{C}$ overnight. Detection of the primary antibody using adequate secondary antibodies followed and was performed as described above. To determine the number of cycling cells in vitro, $10 \mu \mathrm{m}$ of BrdU was added to neurosphere cultures for $2 \mathrm{~h}$ or overnight. Detection of BrdU-positive cells was performed according to the manufacturer's instructions (Roche Products).

Analysis of the adult neurogenic niche and SVZ-derived cells. For immu- nohistochemical analysis, $12 \mu \mathrm{m}$ cryosections from adult mouse forebrain as well as from adult NSC-derived neurospheres grown for 7 div were used. The sections were treated as described above for embryonic cryosections. For NSC cultures, the brains of adult mice were removed from the skull, and 300- $\mu \mathrm{m}$-thick horizontal vibratome sections were prepared for dissection of the SVZ around the lateral ventricle under a high-power stereomicroscope. The SVZ cells were acutely dissociated as described previously (Hartfuss et al., 2001) and plated onto polyornithine-coated dishes in neurosphere medium containing 1\% FCS. After $2 \mathrm{~h}$, adherent cells were fixed and immunocytochemically analyzed with the same antibodies as above. The generation of neurospheres from adult NSCs in the presence of $20 \mathrm{ng} / \mathrm{ml}$ EGF was determined and quantified after 2 weeks in culture. Immunopanning and cell biological analysis were performed as described for embryonic neural progenitor cells.

Chondroitinase $A B C$ treatment. Chondroitinase ABC (ChABC; EC 4.2.2.4; Sigma) was added to neurosphere cultures once at the beginning of the experiment at a concentration of $50 \mathrm{mU} / \mathrm{ml}$, which had been empirically determined as effective concentration using dose-response assays. The efficiency of the digestion of chondroitin sulfateglycosaminoglycans (CS-GAG) was examined by immunocytochemical labeling with $\mathrm{mAb} 473 \mathrm{HD}$, which detects an epitope sensitive to selective deglycanation after ChABC treatment (Faissner et al., 1994). In paralle experiments, the addition of $50 \mathrm{mU} / \mathrm{ml}$ keratanase (Calbiochem, La Jolla, CA) to the culture medium served as a control for the specificity of chondroitin sulfate deglycanation.

Microscopy. All immunofluorescence stainings were analyzed using a fluorescence microscope equipped with UV-epifluorescence (Axioplan 2 imaging; Zeiss). Images were captured with a digital camera and documented using the Axiovision 3.1 or 4.2 program (AxioCamHRc; Zeiss). In some cases, confocal laser-scanning microscopy was applied (LSM510 meta; Zeiss). Standard phase contrast images of living cells were taken using a digital camera (DP10; Olympus, Tokyo, Japan) on an inverted CK40 microscope (Olympus).

Counting and statistical analysis. The proportion of single- and doublelabeled cells from acutely dissociated and selectively isolated cells was determined by counting 200-400 individual cells per independent experiment and epitope. Statistical significance of differences observed between distinct experimental groups was assessed using Student's $t$ test (Excel; Microsoft, Redmond, WA).

\section{Results}

\section{Expression of the 473HD epitope on proliferative precursors in the germinal forebrain regions during corticogenesis}

The mAb 473HD (Faissner et al., 1994) reacts with a complex, sulfation-dependent arrangement of cell-surface-associated CSGAG motifs that contain the CS-D-unit GlcUA(2-O-sulfate)GalNAc(6-O-sulfate) (Clement et al., 1998) as well as the CS-Aunit GlcUA-GalNAc(4-O-sulfate) arranged as an A-D or D-A core recognition sequence (Ito et al., 2005). The $473 \mathrm{HD}$ epitope is also based on dermatan sulfate motives and can be structurally distinguished from the epitopes of the mAbs CS-56 and Mo-225 (Clement et al., 1998; Ito et al., 2005). In the CNS, the 473HD epitope has been found on the two proteoglycan gene products of the receptor protein tyrosine phosphatase- $\beta$ (RPTP $\beta)$ gene, DSD-1-PG/phosphacan and RPTP $\beta$ long (Garwood et al., 1999), that were detected in the ventricular zone (VZ) by in situ hybridization (Canoll et al., 1996; Engel et al., 1996). The 473HD epitope (Ito et al., 2005) was also found in the NSC niche during late development and in the adult CNS (Gates et al., 1995). The developmental onset of expression and the cell type(s) carrying this cell-surface-associated epitope had, however, not been analyzed so far. To establish the temporal sequence of DSD-1 epitope expression, a developmental immunohistochemical analysis was performed. 473HD immunoreactivity was detected from embryonic day E11 onward in the germinal and marginal layers of the forebrain (data not shown). At E13, 473HD expression was found 

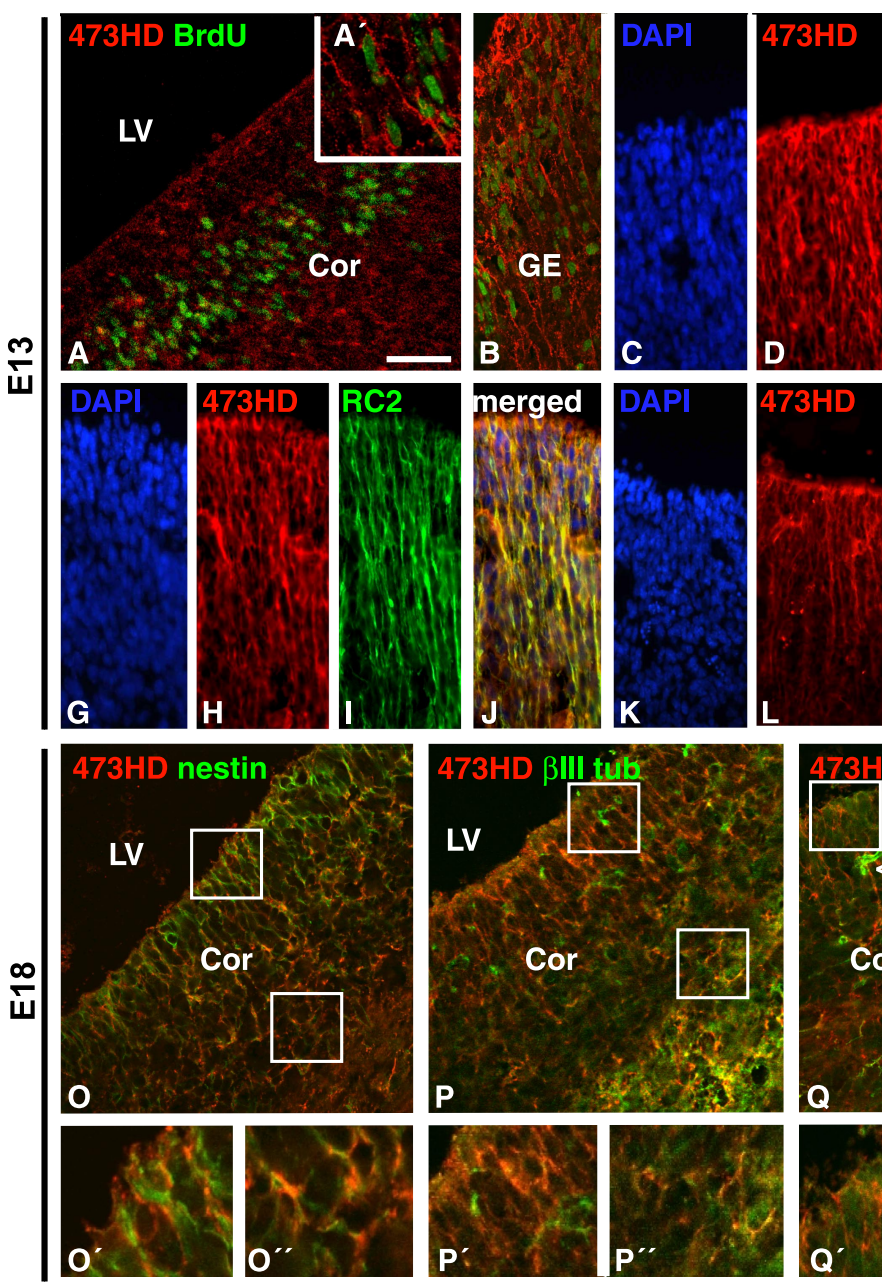

Figure 1. Developmental expression of the 473HD epitope in the telencephalic VZ of the mouse forebrain is closely associated with radial glia. Fluorescence micrographs of frontal sections after double immunostaining with $\mathrm{mAb} 473 \mathrm{HD}$ and various markers, as indicated, are shown. $\boldsymbol{A}, \boldsymbol{B}$, Inspection of the VZ of the forebrain close to the lateral ventricle revealed radially oriented surface expression of the $473 \mathrm{HD}$ epitope on cells that had incorporated $\operatorname{BrdU}\left(\boldsymbol{A}\right.$, cortical VZ; $\boldsymbol{A}^{\prime}$, inset at a higher magnification; $\boldsymbol{B}, \mathrm{VZ}$ of the GE). $\boldsymbol{D}-\boldsymbol{F}$, Double immunolabeling with antibodies against nestin $(\boldsymbol{E})$ demonstrated that many precursor cells in the VZ were $473 \mathrm{HD}$ positive $(\boldsymbol{D}-\boldsymbol{F})$. $\boldsymbol{H}-\boldsymbol{J}$, Staining with $473 \mathrm{HD}(\boldsymbol{H})$ and the radial glia marker $\mathrm{RC2}(\boldsymbol{I})$ yielded colocalization with filament-like radially oriented $\mathrm{RC2}$-positive structures $(\boldsymbol{J})$. $\boldsymbol{L}-\boldsymbol{N}$, Staining with $473 \mathrm{HD}(\boldsymbol{L})$ and the radial glia marker BLBP $(\boldsymbol{M})$, which marks radial glia cells positioned closer to the ventricular surface of the $V Z$, also showed extensive colocalization with 473HD-expressing cells $(\boldsymbol{N})$. C, G, K, Cell nuclei were counterstained with bisbenzimide and visualized using DAPI (4' ,6-diamidino-2-phenylindole) filters. $\mathbf{O}-\mathbf{Q}$, Cryosections of E18 mouse forebrains were studied by double immunofluorescence and confocal analysis with various markers. The boxed areas in the VZ and SVZ are enlarged in the $\mathbf{O}^{\prime}-\mathbf{Q}^{\prime}$ and $\mathbf{O}^{\prime \prime}-\mathbf{Q}^{\prime \prime}$, respectively. The 473HD epitope was preferentially detected on radially oriented nestin-positive precursor cells $(\boldsymbol{0})$ but was barely present on newborn $\beta$ III-tubulinpositive neurons $(\boldsymbol{P})$. Note that there is one $473 \mathrm{HD}, \beta$ III-tubulin-positive cell in $\boldsymbol{P}^{\prime \prime}$. NG2 could mainly be attributed to cells in the perivascular regions $(\boldsymbol{Q}$, arrowhead), whereas the $473 \mathrm{HD}$-immunoreactive cells in the VZ appeared NG2 negative. Individual NG2-positive cells can be observed in the nascent SVZ ( $\left.\boldsymbol{Q}^{\prime \prime}\right)$. Scale bars: $\boldsymbol{A}, \boldsymbol{B}, 50 \mu \mathrm{m} ; \boldsymbol{C}-\mathbf{N}, 30 \mu \mathrm{m} ; \mathbf{0}-\mathbf{Q}, 20 \mu \mathrm{m}$. LV, Lateral ventricle; Cor, cortex; $\beta$ III, $\beta$ III-tubulin.

in the $\mathrm{VZ}$ of the dorsal and ventral telencephalon (Fig. 1A,B). The $473 \mathrm{HD}$ epitope appeared to be present on radially oriented processes in close association with actively cycling BrdU-positive cells (Fig. $1 A^{\prime}$ ), suggesting that these might correspond to radial glia. Double-immunofluorescence analysis revealed that the 473HD immunoreactivity colocalized with the precursor cell marker nestin (Fig. $1 C-F$ ) and with the radial glia cell markers RC2 (Fig. $1 G-J$ ) and BLBP (Fig. $1 K-N$ ). At E18, when neurogenesis is primarily completed in the forebrain and NSCs are progressively giving rise to glial progeny (Temple, 2001), the 473HD epitope still persisted in the germinal layers of the forebrain (Fig. 1O-Q). Similar to results at E13, the expression of the 473HD
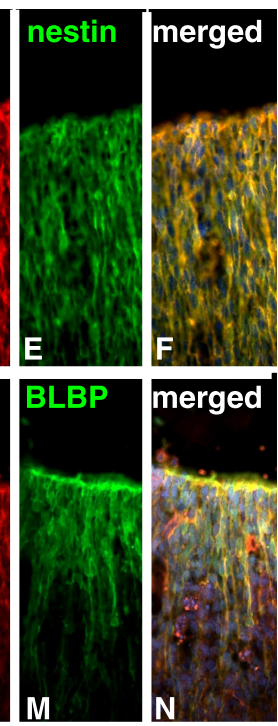

epitope appeared to colocalize with radially oriented nestin-positive precursor cells in the VZ (Fig. 1O). When comparing the nestin and $\beta$ III-tubulin staining (Fig. $1 P)$, it became apparent that the $473 \mathrm{HD}$ epitope was associated with nestinpositive cells but not with newborn neurons in the VZ. Based on observations that the chondroitin sulfate proteoglycan NG2 has been found on glial precursors (DiersFenger et al., 2001) and postnatally on multipotent C-type cells of the adult SVZ (Aguirre et al., 2004), we studied in more detail the possibility of a potential overlap between the 473HD- and NG2-positive precursor cell populations. Within the VZ, NG2 antibodies strongly labeled the perivascular regions yet did not colocalize with the $473 \mathrm{HD}$ epitope in this territory (Fig. 1Q). This is in accordance with reports that did not describe NG2 on neurons or radial glia (Diers-Fenger et al., 2001) and supports the assumption that 473HD-positive cells differ from NG2positive glial precursors in vivo. It is also consistent with observations that did not detect the 473HD epitope on chondroitin sulfate proteoglycans other than phosphacan (Dobbertin et al., 2003). However, we do find some cells in the nascent SVZ that are double-immunopositive for $473 \mathrm{HD}$ and NG2 (Fig. 1Q" ), whereas others appear to coexpress $\beta$ III-tubulin (Fig. $1 P^{\prime \prime}$ ). Together, the observed staining pattern suggested that the mAb 473HD might identify a subpopulation of radial glia during neurogenesis and prompted us to attempt the enrichment of $473 \mathrm{HD}$-positive cells.

Identification of 473HD-expressing cells as mitotically active radial glia cells In light of the reported heterogeneity of radial glia cells (Hartfuss et al., 2001; Malatesta et al., 2003), it seemed warranted to assess whether the 473HD-positive cells are radial glia and which radial glia markers they express. In a first step, the relative number of $473 \mathrm{HD}$-positive cells from the E13 cortex was determined in acutely dissociated cell cultures $2 \mathrm{~h}$ after plating (Fig. $2 \mathrm{~A}-\mathrm{C}$ ). At this stage $473 \mathrm{HD}$-positive cells constituted a minority of $14.6 \pm 5.3 \%$ of the entire cell population. Approximately onehalf of the cells derived from cortical tissue were actively dividing and nestin-positive precursor cells, and one-third were $\beta$ IIItubulin-positive neurons (Table 1). The radial glial cell markers RC2, GLAST, and BLBP were expressed in cells of cortical origin with a frequency of $37.8 \pm 5.2,40.5 \pm 11.8$, and $27.5 \pm 10.6 \%$, respectively (Table 1). To enrich for DSD-1 epitope-expressing cells, an immunopanning protocol was developed based on previous experiences with the isolation of a defined cell population from chick peripheral ganglia (von Holst and Rohrer, 1998). Starting with suspensions of embryonic forebrain tissues, 
473HD-positive cells from the cortex were enriched to $85.2 \pm 9.7 \%(n=10)$ in the immunoselected population, as determined $2 \mathrm{~h}$ after the panning procedure (Fig. 2D-F, Table 1). Hence, the mAb proved well suited for isolation of $473 \mathrm{HD}$ positive cells. The immunocytological analysis of immunoselected 473HDpositive cells from cortical tissue revealed a highly significant increase in the number of nestin-positive (Fig. 2E), BrdU-positive (Fig. 2H), RC2-positive (Fig. 2J), and BLBP-positive (Fig. $2 \mathrm{~N}$ ) cells compared with the nonselected cell population ( $\mathrm{Ta}$ ble 1). We also investigated the expression of the adult NSC marker LeX (Capela and Temple, 2002) as detected with mAb 487 (Streit et al., 1996). The 473HD-positive cells were significantly enriched in 487/ LeX-positive cells (Fig. 2M, Table 1). These results supported the interpretation that the 473HD-positive cells consist of actively cycling, mostly RC2 and BLBPpositive, radial glia cells. Because not all BLBP-positive radial glia cells in the initial nonselected cell population were 473HD positive (27.5 $\pm 10.6 \%$ BLBP positive vs $14.6 \pm 5.3 \% 473 \mathrm{HD}$ positive), the latter appeared to comprise a subpopulation of BLBP-positive radial glia cells. Somewhat unexpectedly, the percentage of $\beta I I I-$ tubulin-positive neurons was unaltered in the $473 \mathrm{HD}$-positive cell population $(29.9 \pm 4.0 \%)$ (Table 1$)$. This may reflect the onset of neuronal differentiation of neurogenic radial glia cells during the isolation procedure and within the initial $2 \mathrm{~h}$ of culture before the immunocytochemical analysis was performed. In this regard, the number is intriguingly close to the fraction of 473HD-positive cells that are BrdU negative $(26.5 \pm 8.7 \% ; n=8)$ and might thus be viewed as neurogenic radial glia cells that have completed their last cell cycle during the immunopanning procedure and are, consequently, committed to neuronal differentiation. However, it cannot be excluded that some neurons might carry the 473HD epitope (Ohyama et al., 2004). It is noteworthy that analogous fractions of fluorescence-activated cellsorted human GFAP-GFP-positive radial glia cells differentiated into neurons within a very short time period when these cells were grown at clonal density in a coculture system on age-matched rat monolayers (Malatesta et al., 2000). In parallel, nonselected versus 473HD-positive cells derived from E13 GEs were subjected to the same immunocytochemical analysis (Table 1). The findings were remarkably similar to those obtained from the E13 cortex. The striatal radial glia cell population was composed of $38.2 \pm 6.0 \%$ RC2-positive, $48.9 \pm 6.4 \%$ GLASTpositive, and $20.7 \pm 3.5$ BLBP-positive cells at E13. However,
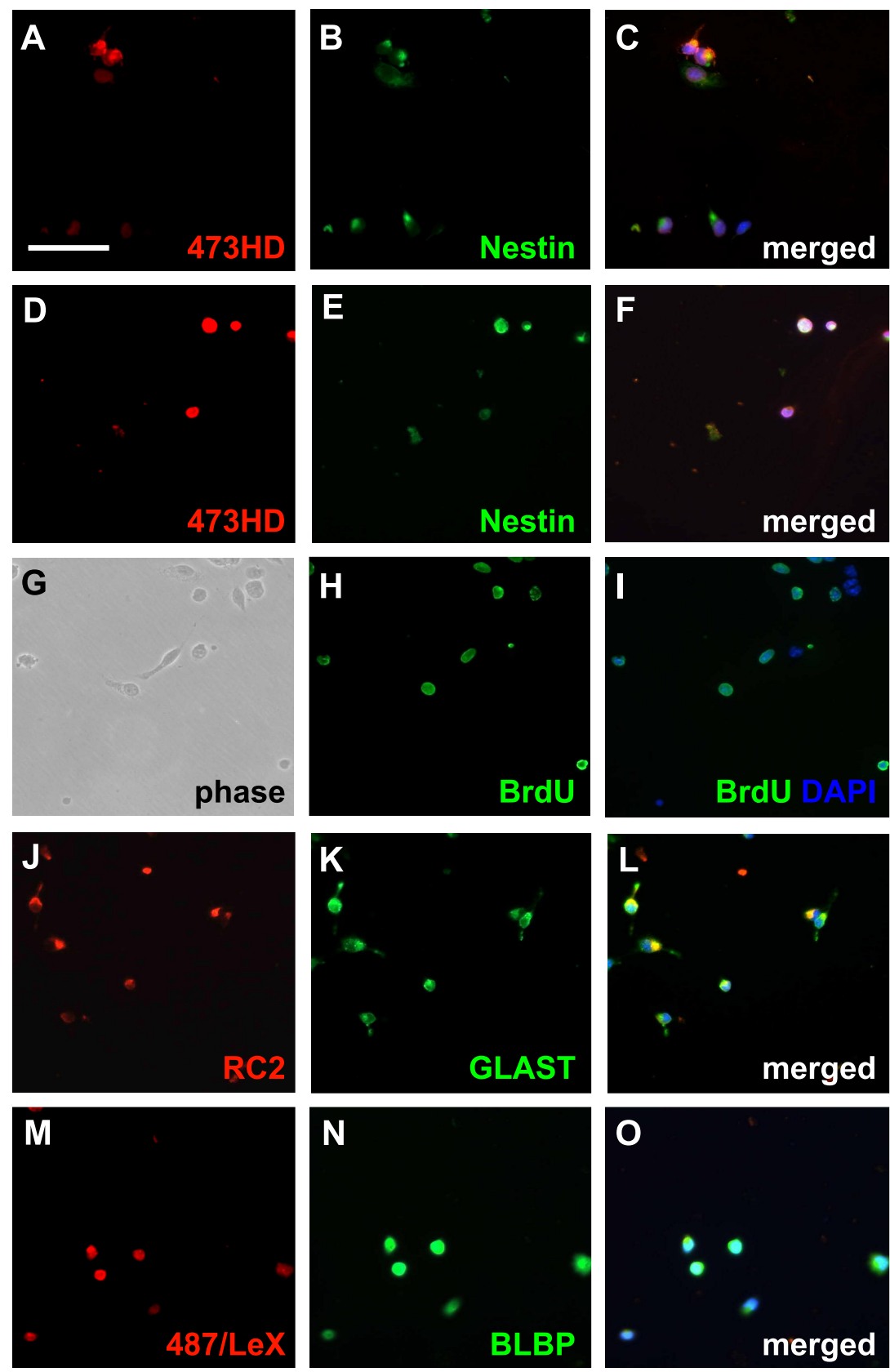

Figure 2. Immunoselection of 473HD-positive cells from E13 forebrain proves their radial glia identity. Acutely dissociated cells from an $\mathrm{E} 13$ cortex were immunostained $2 \mathrm{~h}$ after adhesion and compared with the immunoselected 473HD-positive cell fraction. Representative high-power micrographs are shown to better reveal the immunoreactivity of individual cells. $A, B$, The 473HD epitope $(\boldsymbol{A})$ is only expressed by a fraction of the nestin-positive cells $(\boldsymbol{B}) . \boldsymbol{E}, \mathbf{G}-\boldsymbol{I}$, Analysis of the 473HD-positive cell population shows that most cells are nestin positve $(\boldsymbol{E})$ and that many of them are actively cycling because they incorporated BrdU during a $2 \mathrm{~h}$ pulse in utero $(\mathbf{G}-\mathbf{I}) . \boldsymbol{J}, \boldsymbol{K}, \boldsymbol{M}, \boldsymbol{N}$, The majority of immunoselected $473 \mathrm{HD}$-positive cells also expressed the radial glia cell markers RC2 $(\boldsymbol{J})$, GLAST $(\boldsymbol{K})$, and BLBP $(\boldsymbol{N})$ as well as the adult NSC marker 487/LeX $(\boldsymbol{M})$. The quantitative analysis of immunofluorescence studies with various markers using control cells compared with 473HD-immunopanned cells from an E13 and E18 cortex and GE is shown in the supplemental material (available at www.jneurosci.org). Note that the immunopanning procedure clearly enriches for the 473HD epitope in conjunction with several radial glia markers. $\mathbf{C}, \boldsymbol{F}, \mathbf{I}, \mathbf{L}, \mathbf{0}$, All cell nuclei were counterstained with bisbenzimide and are shown in blue [DAPI (4',6-diamidino-2-phenylindole)]. Scale bar: (in $A) 50 \mu \mathrm{m}$.

after immunopanning, the 473HD-positive cell population was highly and consistently enriched in actively cycling radial glia cells (Table 1). To confirm our immunopanning data and to collect higher numbers of immunopositive cells, we performed immunoisolation of 473HD-positive cells using a magnetic beadbased approach (EasySep). In a single round of immunoisolation, 
Table 1. Quantification of neural cell types during forebrain development

\begin{tabular}{|c|c|c|c|c|c|c|}
\hline \multirow[b]{2}{*}{ Marker } & \multicolumn{3}{|l|}{ Cortex } & \multicolumn{3}{|l|}{ GE } \\
\hline & Nonselected & Selected & $p$ & Nonselected & Selected & $p$ \\
\hline \multicolumn{7}{|l|}{ E13 } \\
\hline 473HD $(n=10)$ & $14.6 \pm 5.3$ & $85.2 \pm 9.7$ & $<0.001$ & $15.6 \pm 3.3$ & $81.2 \pm 7.1$ & $<0.001$ \\
\hline $\operatorname{BrdU}(n=8)$ & $52.5 \pm 5.1$ & $73.5 \pm 8.7$ & $<0.001$ & $29.8 \pm 4.6$ & $69.2 \pm 4.3$ & $<0.001$ \\
\hline Nestin $(n=10)$ & $45.3 \pm 12.9$ & $66.7 \pm 17.3$ & $<0.01$ & $30.6 \pm 8.3$ & $52.3 \pm 10.1$ & $<0.001$ \\
\hline $\mathrm{RC2}(n=9)$ & $37.8 \pm 5.2$ & $82.5 \pm 16.5$ & $<0.001$ & $38.2 \pm 5.9$ & $58.4 \pm 6.6$ & $<0.001$ \\
\hline GLAST $(n=3)$ & $40.5 \pm 11.8$ & $55.4 \pm 2.2$ & NS & $48.9 \pm 6.3$ & $69.6 \pm 2.2$ & NS \\
\hline $\operatorname{BLBP}(n=5)$ & $27.5 \pm 10.6$ & $71.1 \pm 18.9$ & $<0.01$ & $20.7 \pm 3.4$ & $75.9 \pm 3.3$ & $<0.001$ \\
\hline$\beta$ III-Tubulin $(n=10)$ & $29.5 \pm 4.8$ & $29.9 \pm 4.0$ & NS & $30.1 \pm 2.6$ & $30.1 \pm 4.0$ & NS \\
\hline 487/LeX $(n=10)$ & $35.5 \pm 6.2$ & $71.5 \pm 9.5$ & $<0.001$ & $28.9 \pm 10.7$ & $64.2 \pm 10.2$ & $<0.001$ \\
\hline $\operatorname{GFAP}(n=9)$ & $3.2 \pm 1.5$ & 0 & ND & $2.0 \pm 1.1$ & 0 & ND \\
\hline \multicolumn{7}{|l|}{ E18 } \\
\hline 473HD $(n=8)$ & $6.9 \pm 1.2$ & $94.1 \pm 2.3$ & $<0.001$ & $6.4 \pm 0.8$ & $91.7 \pm 3.9$ & $<0.001$ \\
\hline $\operatorname{BrdU}(n=4)$ & $12.9 \pm 0.9$ & $43.1 \pm 7.5$ & $<0.001$ & $20.9 \pm 3.0$ & $45.9 \pm 6.8$ & $<0.001$ \\
\hline Nestin $(n=6)$ & $9.0 \pm 12.9$ & $38.3 \pm 5.6$ & $<0.001$ & $13.4 \pm 1.7$ & $37.3 \pm 7.6$ & $<0.001$ \\
\hline $\mathrm{RC2}(n=6)$ & $10.1 \pm 2.7$ & $46.0 \pm 5.4$ & $<0.001$ & $11.3 \pm 2.7$ & $43.0 \pm 9.3$ & $<0.001$ \\
\hline $\operatorname{BLBP}(n=6)$ & $19.6 \pm 3.4$ & $93.5 \pm 3.3$ & $<0.001$ & $20.8 \pm 4.9$ & $93.2 \pm 3.1$ & $<0.001$ \\
\hline$\beta$ III-Tubulin $(n=10)$ & $29.5 \pm 4.8$ & $29.9 \pm 4.0$ & NS & $43.2 \pm 4.4$ & $28.2 \pm 3.0$ & $<0.001$ \\
\hline 487/LeX $(n=10)$ & $35.5 \pm 6.3$ & $71.5 \pm 9.5$ & $<0.001$ & $22.4 \pm 5.4$ & $88.6 \pm 6.5$ & $<0.001$ \\
\hline $\operatorname{GFAP}(n=6)$ & $8.6 \pm 2.6$ & $4.2 \pm 2.4$ & $<0.01$ & $6.1 \pm 1.2$ & $2.3 \pm 1.1$ & $<0.01$ \\
\hline NG2 $(n=2)$ & $2.2 \pm 1.2$ & $17.2 \pm 1.7$ & NS & $5.7 \pm 1.9$ & $12.4 \pm 1.9$ & NS \\
\hline
\end{tabular}

The percentage of immunoreactive cortical and striatal cells before (nonselected) and after selective isolation via immunopanning with $\mathrm{mAb} 473 \mathrm{HD}$ (selected) is listed. Note that data are expressed as the relative number of immunopositive cells in percentage (mean $\pm S D$ ) of the total cell number counted. $p$ values indicate significance determined by Student's $t$ test. The immunopositive cells were determined $2 \mathrm{~h}$ after acute dissociation of the forebrain tissues and $2 \mathrm{~h}$ after immunopanning with mAb 473HD. n, Number of the independent experiments; NS, nonsignificant; ND, not determined.

Table 2. Marker profile of 473HD-immunopositive cells enriched with paramagnetic beads

\begin{tabular}{lll}
\hline Marker & Cortex & GE \\
\hline 473HD $(n=5)$ & $83.0 \pm 11.5$ & $89.3 \pm 7.7$ \\
BrdU $(n=2)$ & $52.4 \pm 10.0$ & $59.2 \pm 8.6$ \\
Nestin $(n=5)$ & $63.6 \pm 11.8$ & $61.8 \pm 14.4$ \\
RC2 $(n=4)$ & $76.2 \pm 16.5$ & $75.9 \pm 5.7$ \\
BLBP $(n=5)$ & $60.3 \pm 9.5$ & $75.8 \pm 3.9$ \\
$\beta$ HII-Tubulin $(n=5)$ & $31.4 \pm 4.2$ & $30.7 \pm 4.5$ \\
487/LeX $(n=5)$ & $68.1 \pm 12.2$ & $61.4 \pm 15.7$ \\
\hline
\end{tabular}

The percentage of immunoreactive cortical and striatal cells at E13 after selective isolation via EasySep with $\mathrm{mAb}$ $473 \mathrm{HD}$ is shown. Data are expressed as the relative number of immunopositive cells in percentage (mean \pm SD) of the total cell number counted. The immunopositive cells were determined $2 \mathrm{~h}$ after acute dissociation of the forebrain tissues and $2 \mathrm{~h}$ after EasySep with mAb 473HD. $n$, Number of the independent experiments.

we observed an enrichment of 473HD-positive cells from the E13 cortex and GE of $83.0 \pm 11.5$ and $89.3 \pm 7.7 \%$, respectively $(n=$ 5) (Table 2), which is in good agreement with the results obtained by immunopanning. The marker analysis of the 473HD-positive cell population obtained by the EasySep protocol also confirmed the radial glia identity of the $473 \mathrm{HD}$-positive cells (Table 2). When the number of 473HD-positive cells at later stages of telencephalic development was determined, we found that the percentage of 473HD-positive cells had declined to $6.9 \pm 1.2 \%(n=$ $8)$ and $6.4 \pm 0.8 \%(n=8)$ in E18 cortical and striatal tissue, respectively, which represents less than one-half of the fraction detected at E13. In this situation, almost all immunoselected 473HD-positive cells were BLBP positive, with nearly one-half of them showing BrdU incorporation, nestin immunoreativity, and RC2 immunoreativity (Table 1), which identified them as radial glia cells. In addition, the immunoselected cells displayed a pronounced coexpression of the adult NSC marker LeX (cortex: $71.5 \pm 9.5 \%, n=10 ; \mathrm{GE}: 88.6 \pm 6.5, n=10)$. In accordance with the immunohistological analysis, only a minority of the $473 \mathrm{HD}$ positive cells were NG2 positive (cortex: $17.2 \pm 1.7, n=2$; GE: $12.4 \pm 1.9, n=2$ ). These may comprise early immature oligodendroglial cells that coexpress both chondroitin sulfate- proteoglycans (Faissner et al., 1994; Horner et al., 2002). Alternatively, the NG2positive cells could originate from the residual 5\% non-473HD-expressing cells that are contained in preparations with a purification degree of $\sim 95 \% \quad 473 \mathrm{HD}$ positive cells. Together, these results support the view that the complex chondroitin sulfate epitope detected by the 473HD mAb (Clement et al., 1998; Ito et al., 2005) can also be used to enrich for mitotically active neurogenic radial glia cells from dorsal and ventral forebrain at the beginning of gliogenesis.

\section{The 473HD-positive subpopulation of radial glia cells showed characteristics of NSCs}

The ability to selectively isolate a subpopulation of radial glia cells allowed for further characterization of the cell biological properties of the $473 \mathrm{HD}$-positive population. When plated on a poly-ornithine/ laminin substrate, the majority of the 473HD-positive cells differentiated into $\beta$ III-tubulin-positive cells with an immature morphology within $2 \mathrm{~d}$ of culture (Fig. $3 A-C$ ). Not surprisingly, given the fast onset of neuronal differentiation after immunopanning (see above) and the fate of BLBP-positive radial glia cells during neurogenesis (Anthony et al., 2004), $>80 \%$ of the $473 \mathrm{HD}$-positive cells from both the cortex and GE at E13 became young neurons after 2 div (Fig. 3G). It is known that the cortex and GE give rise to distinct neuronal subpopulations. Because of the immature morphologies observed after 2 div and the lack of knowledge concerning the conditions for the differentiation of neuronal lineages in culture, we did not investigate further which neuronal subtypes were preferentially generated in our assay. To investigate whether the immunoselected population contained NSCs, 473HD-positive cells were cultivated in suspension under neurosphere-forming conditions. Neurospheres serve as the best available model for NSCs because they can self-renew and are multipotent, giving rise to neurons, astrocytes, and oligodendrocytes. In E13 low-density clonal cultures, the formation of neurospheres from 473HD-positive cells was observed (Fig. 3D,E). The total number of neurospheres was counted after 6 div, and the $473 \mathrm{HD}$-positive cells displayed a significant increase in the capacity to generate neurospheres. Thus, the frequency of neurosphere-forming units rose from $4.7 \pm 1.2 \%$ in the nonsorted initial cell suspension plated from cortical tissue to $14.3 \pm$ $3.5 \%$ of the $473 \mathrm{HD}$-immunoselected population $(n=3$; $p<$ 0.01 ) (Fig.3H and supplemental Fig. 1, available at www.jneurosci. org as supplemental material). Similarly, the number of cells forming neurospheres was significantly increased from $6.9 \pm 2.2$ to $20.0 \pm 8.0 \%(n=3 ; p<0.05)$ (Fig. $3 \mathrm{H}$ and supplemental Fig. 1 , available at www.jneurosci.org as supplemental material), when nonselected and 473HD-positive, GE-derived cell suspensions were compared. These results clearly demonstrate that the 473HD-positive cell population contained an increased fraction of cells with NSC-like properties. With the aim to explore this aspect further, the 473HD-positive cell-derived neurospheres were probed for multipotency and self-renewal. As expected, neurospheres derived from 473HD-positive cells differentiated normally (Fig. $3 F$ ), giving rise to $\beta$ III-tubulin-positive neurons, 

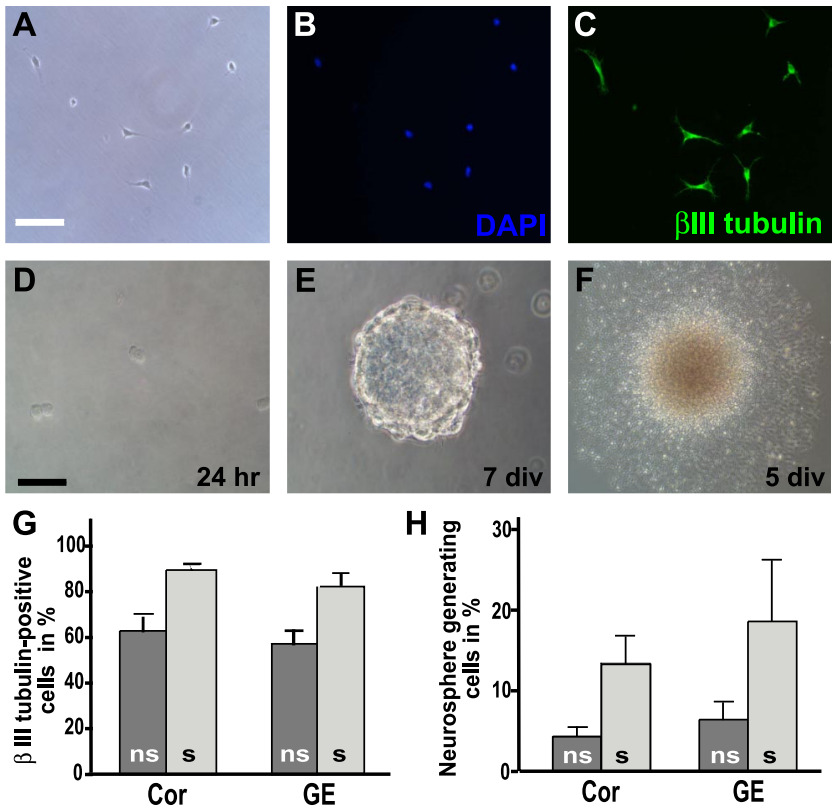

Figure 3. Selectively isolated 473HD-positive precursor cells differentiate into neurons or form neurospheres in suspension cultures. Cells were sorted from E13 mouse cortex and GE cell suspensions by immunopanning using $\mathrm{mAb} 473 \mathrm{HD}$ and were subsequently cultured on laminin for $2 \mathrm{~d}$. $\boldsymbol{A}$-C, Immunocytochemical staining with established markers clearly indicated that the majority of cells differentiated into immature neurons $(\boldsymbol{C})$ under these conditions $(\boldsymbol{A}-\boldsymbol{C})$. $\boldsymbol{A}$ and $B$ show the phase contrast and labeled nuclei images, respectively, corresponding to the $\beta$ IIItubulin staining shown in $\boldsymbol{C}$. $\boldsymbol{D}, \boldsymbol{E}$, When cultured under neurosphere-forming conditions in the presence of EGF and bFGF, the sorted 473HD epitope-expressing cells began to divide within $24 \mathrm{~h}(\boldsymbol{D})$ and formed multicellular neurospheres after $7 \mathrm{~d}(\boldsymbol{E})$. $\boldsymbol{F}$, These neurospheres differentiated morphologically and gave rise to neurons and glia (see supplemental Fig. 2, available at www.jneurosci.org as supplemental material) revealing their multipotency. $\mathbf{G}$, The graph shows the percentage of $\beta$ III-tubulin-immunoreactive neurons (mean \pm SD) obtained from 473HD-immunoselected (s, light gray bars) compared with nonselected control (ns, dark gray bars) cells from dorsal (Cor) and ventral (GE) telencephalic tissue. $\boldsymbol{H}$, The graph shows the fraction of neurosphere-forming cells (mean \pm SD) in the nonselected control (ns, dark gray bars) compared with the 473HD-enriched (s, light gray bars) cell population from both the cortex (Cor) and GE that increases threefold in the immunoselected 473HD-positive cell populations derived from cortical and striatal tissues. The cell nuclei were counterstained with bisbenzimide and are shown in blue [DAPI (4',6-diamidino-2-phenylindole)] (B). Scale bars: $\boldsymbol{A}-\boldsymbol{F}, 50 \mu \mathrm{m}$.

O4-positive oligodendrocytes, and GFAP-positive astrocytes (supplemental Fig. 2, available at www.jneurosci.org as supplemental material). When neurospheres generated from 473HDpositive cells were dissociated, secondary neurospheres formed showing their capacity to self-renew (data not shown). We performed the same assay strategy with immunoselected 473HDpositive cells isolated from E18 forebrain. Similar to the situation at E13, the 473HD-positive cells differentiated primarily into immature $\beta$ III-tubulin-positive neurons on a laminin substrate within 2 div (data not shown). This neurogenic capacity during the gliogenic phase of forebrain development might be counterintuitive but could be inferred already several hours after the isolation procedure when $29.9 \pm 4.0 \% \beta$ III-tubulin-positive cells were observed ( $n=10$ ) (Table 1$)$. Under neurosphere-forming conditions, the $473 \mathrm{HD}$-positive cells gave rise to significantly more neurospheres than the nonselected cell population (data not shown). Together, the cell biological analysis at both E13 and E18 confirmed that the $473 \mathrm{HD}$-positive cell population consisted of neurogenic radial glia and cells with NSC-like properties from both dorsal and ventral forebrain tissues (Table 1).
The 473HD-positive cell population in neurospheres as an unlimited source of NSCs

The above findings prompted us to investigate the expression and the cell biological properties of $473 \mathrm{HD}$-positive cells in neurospheres, which serve as a widespread model for NSCs. Immunohistochemical staining of cryosections of neurospheres grown for $7 \mathrm{~d}$ in culture revealed a strong expression of $473 \mathrm{HD}$, which was colocalized with nestin (Fig. $4 A-D$ ). The expression appeared to be more intense on the outer cell layers of the neurosphere where actively cycling cells are located (Campos et al., 2004). In doubleimmunofluorescence studies, BrdU-positive and 473HDpositive cells colocalized in the outer cell layers of the neurospheres (Fig. 4E) after short-term as well as after overnight pulses. After the identification of $473 \mathrm{HD}$-positive cells as radial glia in vivo (see above), we also examined the colocalization of the $473 \mathrm{HD}$ epitope with radial glia markers in neurosphere sections by confocal analysis. A considerable overlap with RC2-, BLBP-, and GLAST-positive cells could be detected (Fig. 4F, $H$, respectively). The coexpression of the cell-surface epitope 473HD appeared to be strongest with GLAST, which is probably a consequence of its plasma membrane localization compared with the cytoplasmatic proteins RC2 and BLBP. In summary, these findings suggested that the cell-type-specific expression of the 473HD epitope might be conserved in culture and comparable to the in vivo situation. Therefore, the cellular composition of cortical and striatal neurospheres before and after isolation of the 473HDpositive cells by immunopanning was quantitatively analyzed (Fig. $4 I, J)$. It could be confirmed that neurospheres contain a complex mixture of different cell types, as has been stated previously (D'Amour and Gage, 2003; Campos et al., 2004). E13 cortical neurospheres after 7 div contained $78.5 \pm 8.5 \%$ BLBPpositive radial glia cells, $5.6 \pm 5.1 \% \quad \beta$ III-tubulin-positive neurons, and $7.7 \% \pm 2.5 \%$ GFAP-positive astrocytes $(n=3)$. Approximately $40 \%$ of the total cell number were BrdU positive after a $15 \mathrm{~h} \mathrm{BrdU}$ pulse, and the 473HD-positive cells constituted $41.8 \pm 9.4 \%(n=3)$. After a shorter BrdU pulse, fewer cells were labeled, but the frequency of $473 \mathrm{HD}$-positive cells appeared similar (data not shown). The analysis of striatal neurospheres showed similar results with $74.5 \pm 4.1 \%$ of the cells identified as nestin-expressing precursors, $11.9 \pm 6.2 \% \beta$ III-tubulin-positive neurons, and $5.4 \% \pm 1.5 \%$ GFAP-positive astrocytes $(n=3)$. Thus, neurospheres do not only represent a composite mixture of cells but apparently consist primarily of heterogeneous radial glia cells. We suspected that the 473HD-positive cells could, by themselves, constitute a subpopulation of the BLBP-positive radial glia cells. Indeed, after immunopanning almost all of the 473HDpositive cells were BLBP positive. Approximately $60 \%$ of the $473 \mathrm{HD}$-positive cells were actively cycling as determined by BrdU incorporation. Also, the majority of 473HD-positive cells coexpressed the adult NSC marker LeX (Fig. 4I,J). Again, the cellular behavior of the $473 \mathrm{HD}$-positive cell population was determined. In accordance with the findings obtained with acutely immunoselected 473HD-positive cells from different stages in vivo, $\sim 80 \%$ of the $473 \mathrm{HD}$-positive cells differentiated to immature $\beta$ III-tubulin-positive neurons under adherent conditions on a laminin substrate within $2 \mathrm{~d}$ in culture (Fig. $4 K$ ). When the neurosphere-derived 473HD-positive cells were tested for their neurosphere-forming capacity in clonal density assays, a twofold increase in the total number of secondary neurospheres was observed (Fig. $4 \mathrm{~L}$ ). More importantly, the 473HD-negative immunodepleted cell population had primarily lost the capacity to form neurospheres (Fig. 4L). Compared with the 473HDnegative cell fraction, immunoselection of 473HD-positive cells 

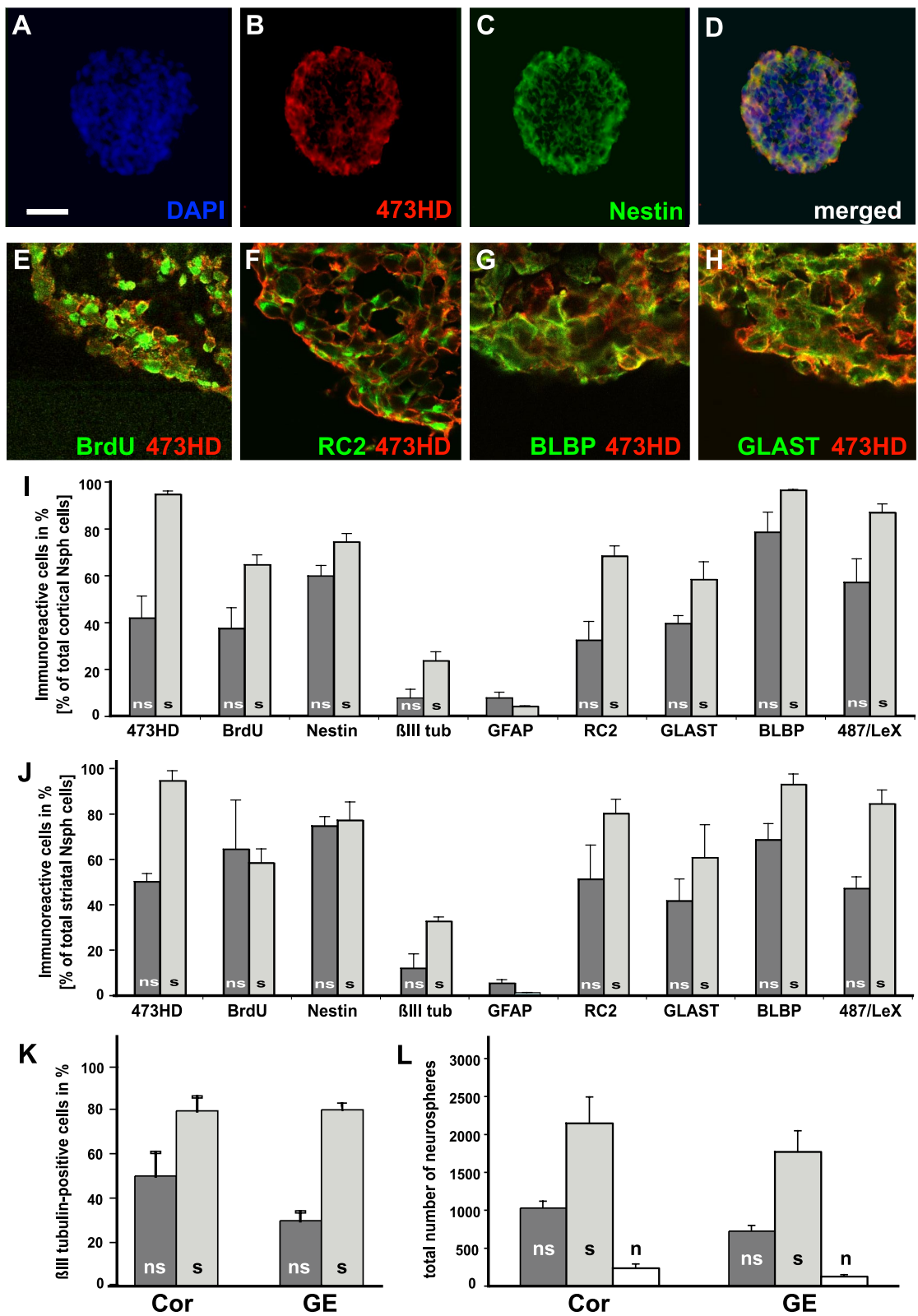

Figure 4. The 473HD epitope is expressed in neurospheres on actively cycling radial glia cells that comprise the neurosphereforming cell population. Photomicrographs of cryosections of forebrain-derived neurospheres labeled with mAb 473HD and antibodies to nestin are shown. $A-D$, Note the extensive codistribution of the 473HD epitope with nestin-positive cells in the outer cell layer of the neurosphere. $\boldsymbol{E}-\boldsymbol{H}$, Using confocal laser-scanning microscopy, many of the cells labeled with BrdU after a $15 \mathrm{~h}$ pulse were found to express the $473 \mathrm{HD}$ epitope $(\boldsymbol{E})$. Similarly, a coexpression of $473 \mathrm{HD}$ with the radial glia cell markers $\mathrm{RC}(\boldsymbol{F}), \operatorname{BLBP}(\boldsymbol{G})$, and GLAST $(\boldsymbol{H})$ could be demonstrated. Quantitative analyses of dissociated cell suspensions obtained from E13 neurospheres were performed and compared with those enriched by immunopanning with $\mathrm{mAb} 473 \mathrm{HD}$. All cells were counterstained with bisbenzimide and are shown in blue [DAPI (4',6-diamidino-2-phenylindole)] (A), except for the confocal images $(\boldsymbol{E}-\boldsymbol{H}) . \boldsymbol{I}, \boldsymbol{J}, \boldsymbol{T h e}$ percentage of positive cells for the various markers is shown for the acutely dissociated nonselected (ns, dark gray bars) compared with the immunoselected (s, light gray bars) 473HD-positive cell population. This set of data revealed that $>50 \%$ of the $473 \mathrm{HD}$ positive cells were BrdU positive (collected from neurospheres labeled with a $15 \mathrm{~h}$ BrdU pulse) and expressed the marker nestin. Interestingly, many 473HD-immunoselected cells coexpressed the radial glial cell markers RC2 and GLAST, and almost all were BLBP and 487/LeX positive. The bar graph displays the results of the quantitative analysis (mean \pm SD) of cells obtained from cortical $(\boldsymbol{I})$ and striatal $(\boldsymbol{J})$ neurospheres. $\boldsymbol{K}$, The cell biological comparison of the immunoselected 473HD epitope-expressing cells ( $s$, light gray bars) with the nonselected control population ( $n s$, dark gray bars) from cortical (Cor) and striatal (GE) neurospheres showed an increase in the relative number of $\beta$ III-tubulin-positive neurons rising from 25 to $80 \%$ when grown for $2 \mathrm{~d}$ on laminin. $\boldsymbol{L}$, In parallel, the emergence of neurospheres from these cell populations was monitored in clonal density assays. Note that the fraction of neurosphere-forming cells (mean \pm SEM) could be significantly increased $(n=3)$ in the positively selected 473HDpositive cell population (s, light gray bars), whereas the negatively selected cell population ( $\mathrm{n}$, open bars) was almost completely depleted of neurosphere-forming cells $(n=3)$ in cell populations obtained from both cortical and striatal neurospheres after immunopanning with 473HD. Scale bar: (in $\boldsymbol{A}) \boldsymbol{A}-\boldsymbol{D}, 50 \mu \mathrm{m} ; \boldsymbol{E}-\boldsymbol{H}, 10 \mu \mathrm{m}$. $\beta$ III tub, $\beta$ III-Tubulin. resulted in a significant 6- to 15 -fold enrichment of neural stem/progenitor cells from cortical and striatal neurospheres, respectively $(n=3)$. This suggests that neurosphere-derived neural stem/progenitor cells are characterized by the expression of complex CS-GAGs that are recognized by the mAb 473HD.

Mitotically active cells from the adult SVZ are 473HD positive

Next, we focused our analysis on cells within the adult neurogenic stem cell niche. The immunohistochemical analysis of adult forebrain with $\mathrm{mAb} 473 \mathrm{HD}$ confirmed a strong expression of DSD-1-PG/ RPTP $\beta$ in the SVZ of the lateral ventricle wall (Fig. 5A) (Gates et al., 1995). At higher magnification, it became apparent that some 473HD-positive cells within the SVZ coexpress GFAP (Fig. $5 B^{\prime}-B^{\prime \prime \prime}$ ), whereas the majority were GFAP negative (Fig. $5 C$ $\left.C^{\prime \prime \prime}\right)$. The $473 \mathrm{HD}$ epitope was also expressed in the subgranular zone of the dentate gyrus (Fig. 5D), the other site of ongoing neurogenesis in the adult CNS (Kempermann et al., 2004), where it could be detected on some GFAP-positive cells (Fig. $\left.5 D^{\prime}-D^{\prime \prime \prime}\right)$. In both adult neurogenic regions, a colocalization of the $473 \mathrm{HD}$ epitope with GLAST was found (Fig. $5 E-G$ and data not shown), which has been described for the adult SVZ in the rat CNS (Braun et al., 2003). These findings imply that the expression of DSD-1-PG/RPTP $\beta$ could be localized on adult neural progenitor cells within the neurogenic regions of the adult mouse forebrain. We tested this assumption by immunocytochemical analysis of acutely dissociated SVZ cells that were microdissected from horizontal vibratome sections of the adult brain under a high-power stereomicroscope. We found that $39.4 \pm 6.9 \%(n=5)$ of the SVZ cell population was $473 \mathrm{HD}$ positive and could be enriched by immunopanning to $86.8 \pm 7.2 \%(n=7)$. The comparison of immunoselected 473HD-positive cells with the nonselected adult SVZ cell suspension using immunocytochemical markers (Fig. 6E) demonstrated that almost all 473HD-positive cells were actively cycling $(87.4 \pm 7.4 \% ; n=4)$ (Fig. $6 A, B)$ and coexpressed $487 / \mathrm{LeX}(82.1 \pm 4.5 \%$; $n=6$ ) (Fig. $6 C, D$ ). In accordance with the immunohistochemical stainings (Fig. 5), the percentage of 473HD-positive cells expressing GFAP was low $(5.1 \pm 1.3 ; n=7)$ (Fig. 6E). Similarly, we found very little coexpression of NG2 $(2.8 \pm 1.4 ; n=2)$ on $473 \mathrm{HD}$-positive cell isolated from the SVZ of the lateral ventricle wall. These observations suggested that the $473 \mathrm{HD}$ epitope is 
present on adult NSCs (Capela and Temple, 2002), on fast-cycling C-type cells (Doetsch et al., 2002), as well as on some A-type neuroblasts. The latter were enriched threefold in the immunoselected $473 \mathrm{HD}$-positive cell population as determined by the expression of $\beta$ III-tubulin $(43.7 \pm 7.5 \% ; n=7)$ (Fig. $6 E$ ) and PSA$\operatorname{NCAM}(46.3 \pm 11.8 ; n=2)$.

Interestingly, the $473 \mathrm{HD}$ epitopeexpressing cells displayed consistent cell biological characteristics. Analogous to the observations with embryonic 473HDexpressing cells, the majority of the selectively isolated $473 \mathrm{HD}$-positive cells from the adult SVZ differentiated into immature $\beta$ III-tubulin-positive neurons after 2 $\operatorname{div}$ (Fig. 6F, G), in accordance with the fact that adult neural progenitor cells of the SVZ generate neurons in vivo (Gage, 2000). When grown under neurosphereforming conditions, $11.3 \pm 2.4 \%(n=2)$ of the $473 \mathrm{HD}$-positive cells generated neurospheres, which represents a sixfold increase over the unsorted cell population. We next examined neurospheres generated from adult NSCs in the presence of EGF and bFGF. Immunohistochemical staining of neurosphere sections demonstrated the localization of the $473 \mathrm{HD}$ epitope on nestin-positive (Fig. $6 \mathrm{H}-\mathrm{K}$ ) and on 487/LeX-expressing cells (Fig. $6 \mathrm{~L}-\mathrm{O})$ in the outer cell layers of the neurospheres. The analysis of the $473 \mathrm{HD}$ positive cells derived from adult neurospheres after immunopanning confirmed that most of the selectively isolated 473HD-expressing cells incorporated BrdU after a $15 \mathrm{~h}$ BrdU pulse, were 487/ LeX positive, and differentiated into immature $\beta$ III-tubulin-positive neurons in vitro (data not shown). These analogous observations obtained with 473HDpositive cells derived from the adult SVZ or from adult neurospheres clearly support the notion that the enrichment of adult neural stem/progenitor cells through the $473 \mathrm{HD}$ epitope is possible. Together, we found that the $473 \mathrm{HD}$ epitope is present on radial glia cells with NSC properties throughout telencephalic development and is maintained in the adult NSC niche. This finding closely fits with the concept that the NSCs represent a radial glia lineage continuum (Doetsch, 2003; Tramontin et al., 2003).

\section{Interference with CS-GAGs inhibits neurosphere formation} of the immunoselected $473 \mathrm{HD}$-positive cell population

Our studies so far demonstrated the presence of the $473 \mathrm{HD}$ epitope on actively cycling cells that were also characterized by their ability to self-renew as neurospheres. Therefore, we hypothesized that cell-surface-associated chondroitin sulfate motifs might regulate the proliferative capacity of $473 \mathrm{HD}$-positive NSCs. This also seemed plausible with regard to studies that had highlighted the importance of chondroitin sulfates for develop-
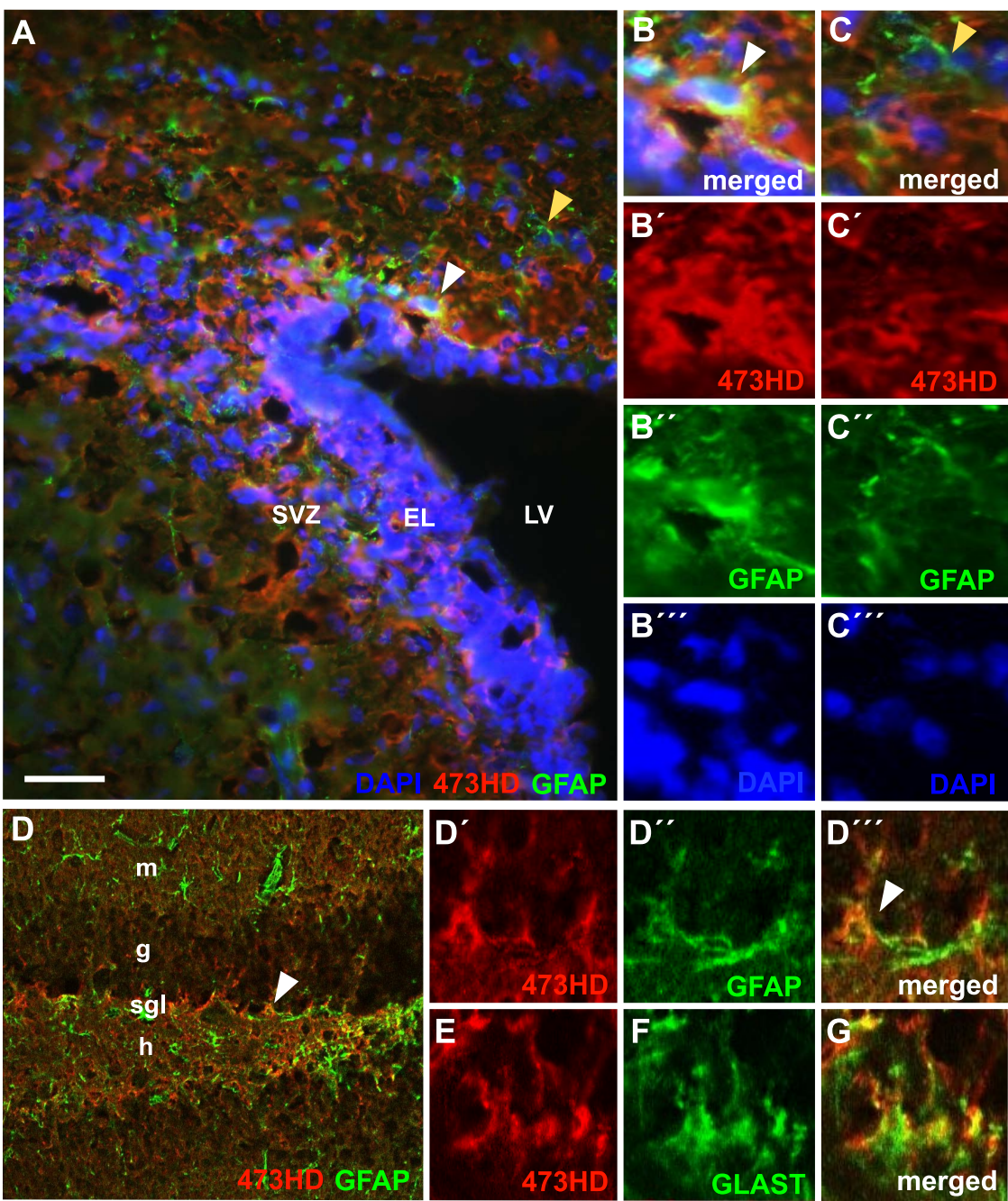

Figure 5. The 473HD epitope is expressed in the neurogenic niches of the adult brain. $A-D$, The photomicrographs show double-immunofluorescence images of 473HD epitope expression in red (CY3) and GFAP expression in green (CY2) in the adult SVZ 列 f colocalizes with GLAST. All cell nuclei were counterstained with bisbenzimide and are shown in blue [DAPI (4',6-diamidino-2phenylindole)], except for the confocal images $(\boldsymbol{D}-\boldsymbol{G})$. Scale bar: (in $\boldsymbol{A}) \boldsymbol{A}, 50 \mu \mathrm{m} ; \boldsymbol{D}, 100 \mu \mathrm{m}$; high-power images, $10 \mu \mathrm{m}$. EL, Ependymal layer; g, granular layer; $h$, hilus; LV lateral ventricle; $m$, molecular layer.

mental biology in Caenorhabditis elegans. In that model, mutant animals that are devoid of CS-GAGs displayed severely compromised cell division and vulval morphogenesis (Hwang et al., 2003; Mizuguchi et al., 2003). The bacterial enzyme ChABC specifically degrades CS-GAGs but does not directly affect the core proteins of chondroitin sulfate proteoglycans (Bradbury et al., 2002). First, the compatibility and efficiency of the removal of surface-expressed CS-GAGs by ChABC treatment was determined in adherent single-cell cultures by doubleimmunofluorescence using the antibodies 473HD and pk-antiphosphacan (Faissner et al., 1994). The latter recognizes the protein cores of the proteoglycan DSD-1-PG/phosphacan and its receptor variant RPTP $\beta$ (Garwood et al., 1999). Immunocytochemical staining of cells maintained for $2 \mathrm{~d}$ in culture in the absence of ChABC revealed the expression of the $473 \mathrm{HD}$ epitope (Fig. $7 B$ ) that was colocalized with pk-anti-phosphacan immu- 

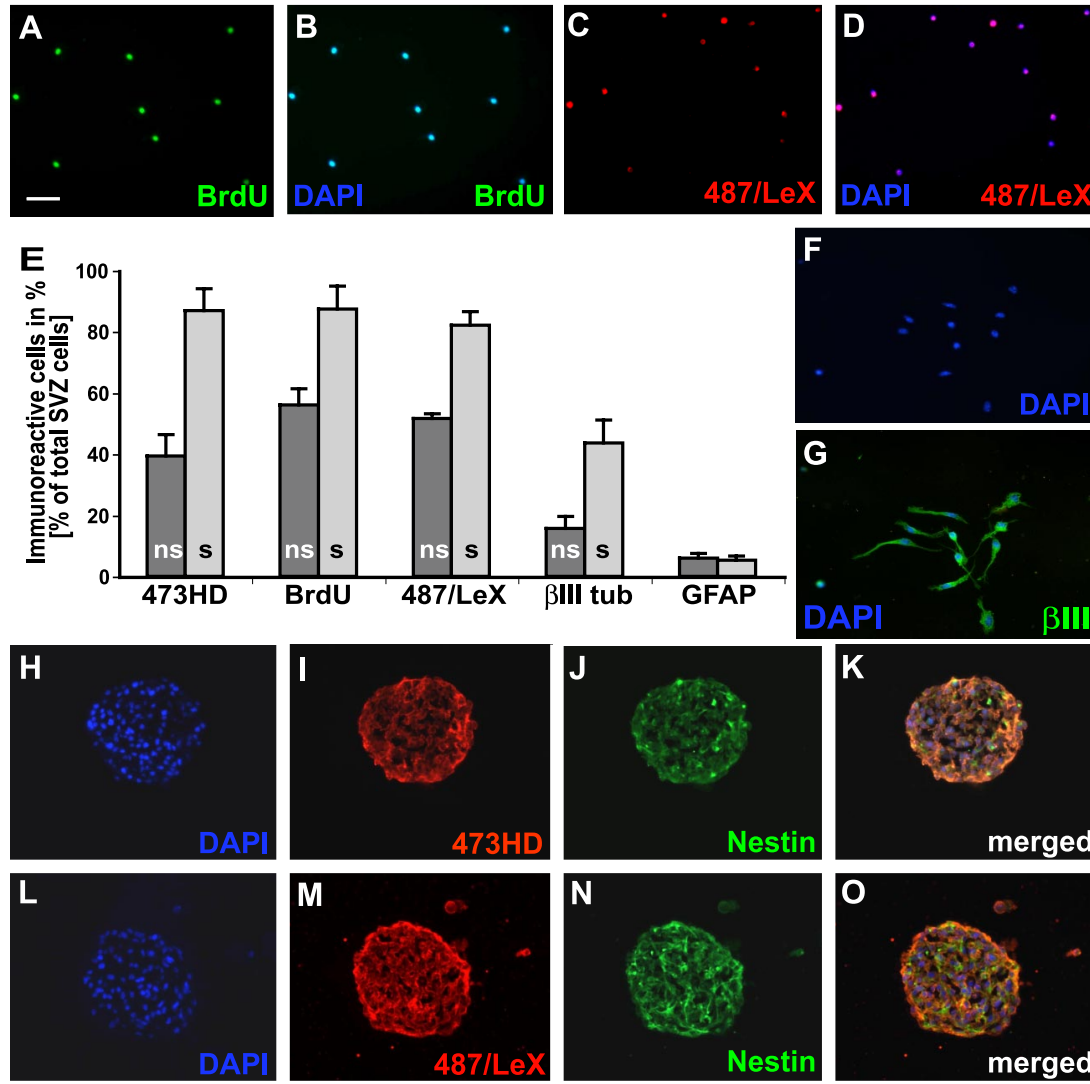

Figure 6. The 473HD epitope is expressed on actively cycling 487/LeX-positive cells of the SVZ and in adult SVZ-derived neurospheres. $\boldsymbol{A}-\boldsymbol{D}$, This set of data revealed that $\sim 90 \%$ of the $473 \mathrm{HD}$-positive cells were BrdU positive $(\boldsymbol{A}, \boldsymbol{B})$ and expressed the adult NSC 487/LeX $(\boldsymbol{C}, \boldsymbol{D})$. Interestingly, the immunoselected $473 \mathrm{HD}$-positive cell population comprised $\sim 50 \% \beta \mathrm{Bll}$-tubulinpositive cells $2 \mathrm{~h}$ after plating, suggestive of type A cells (neuroblasts). $\boldsymbol{E}$, The quantitative analysis (mean \pm SD) of dissociated cell suspensions obtained from a microdissected adult SVZ was performed and compared with the one derived from cell suspensions enriched by immunopanning with $\mathrm{mAb} 473 \mathrm{HD}$. The percentage of positive cells for the various markers is shown for the acutely dissociated nonselected (ns, dark gray bars) compared with the immunoselected (s, light gray bars) 473HD-positive cell population. $\boldsymbol{F}, \mathbf{G}$, Consequently, when grown for $2 \mathrm{~d}$ on laminin, most of the immunoselected 473HD epitope-expressing cells became immature $\beta$ III-tubulin-positive neurons. $I, J, M, N$, Photomicrographs of cryosections of adult neurospheres derived from SVZ cells after 14 din culture labeled by double immunofluorescence with mAb 473HD $(\boldsymbol{I})$ and antibodies to nestin $(\boldsymbol{J}, \boldsymbol{N})$ and $487 / \mathrm{LeX}(\boldsymbol{M})$. $K, \mathbf{0}$, Note the extensive codistribution of the 473HD epitope with nestin- and 487/LeX-positive cells in the outer cell layer of the neurospheres. $\boldsymbol{H}, \boldsymbol{L}$, All cell nuclei were counterstained with bisbenzimide and are shown in blue [DAPI (4',6-diamidino-2phenylindole)]. Scale bar: (in $\boldsymbol{A}) \boldsymbol{A}-\mathbf{G}, 30 \mu \mathrm{m} ; \boldsymbol{H}-\mathbf{0}, 50 \mu \mathrm{m}$. $\beta$ III tub and $\beta$ III, $\beta$ III-Tubulin.

noreactivity (Fig 7C,D). When the enzyme ChABC was added to the culture medium, the $473 \mathrm{HD}$ epitope was almost completely abolished (Fig. $7 F$ ), whereas many 473HD-negative cells still displayed the protein cores of DSD-1-PG/RPTPb (Fig 7G,H). These experiments showed that the neural stem/progenitor cells tolerate the addition of $\mathrm{ChABC}$ to the culture medium. Hence, 473HD epitope-expressing cells from dorsal and ventral regions of E13 forebrain as isolated by immunopanning and cultivated under neurosphere-forming conditions could be studied either in the presence or in the absence of ChABC. The number of neurospheres that formed under either condition was determined after 5 div using bulk cultures. The removal of CS-GAGs led to a significant reduction in the number of neurospheres, which was more pronounced when the $473 \mathrm{HD}$-positive cells were derived from cortical as compared with striatal tissue (threefold vs twofold reduction) (Fig. 7I). The reduction in the number of neurospheres formed under ChABC treatment was dose dependent, saturating at $200 \mathrm{mU} / \mathrm{ml}$ (supplemental Fig. 3, available at www. jneurosci.org as supplemental material). To control for the specificity of the ChABC effect, an analogous experiment was per-
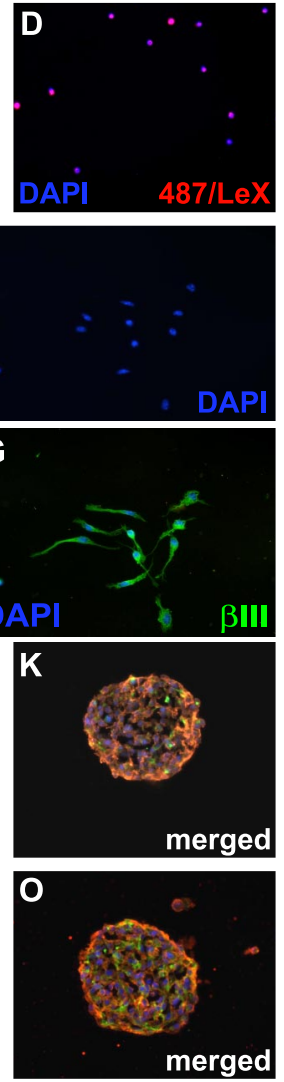

formed in which neurospheres were exposed to the GAG-lyase keratanase instead of ChABC. This treatment resulted in $473 \mathrm{HD}$ staining patterns indistinguishable from control neurospheres (data not shown). Furthermore, no difference in the numbers of emerging neurospheres was recorded. Thus, the removal of CS-GAGs from 473HD-positive telencephalic neural progenitor cells revealed a selective and specific requirement of these particular carbohydrates with respect to the rate of neurosphere formation. It is worth pointing out that these effects could be observed in the presence of heparin, a component that resists degradation by $\mathrm{ChABC}$ treatment and is supposed to enhance the bFGF-dependent effects of the standard culture medium for neurospheres. These observations were confirmed when we assayed for neurosphere formation in clonal density assays (Garcion et al., 2004) in the absence or presence of ChABC (Fig. $7 J$ ). Moreover, the addition of the $\mathrm{mAb}$ $473 \mathrm{HD}$ to the $473 \mathrm{HD}$-positive cell population in clonal density assays resulted in a similar decrease in the number of neurospheres. To control for the specificity of this reduction, we added the same amount of the isotype-matched mAb 487/LeX, the epitope of which is also surface expressed by these cells (Table 1). However, the addition of the mAB 487/LeX did not cause a reduction in the number of neurospheres formed after $7 \mathrm{div}$ (Fig. 7J). In addition, we observed that the addition of ChABC caused the adherence of neurospheres to the untreated culture dishes from the third day in culture onward (supplemental Fig. 4, available at www.jneurosci.org as supplemental material). Given the late onset of this effect and the failure of the neurospheres to adhere to the plastic surface when ChABC is removed from the medium after 3 div, it seems unlikely that this adhesion phenomenon is sufficient to explain the difference in the number of neurospheres registered in control and ChABC-treated cultures of immunoselected 473HDpositive cells. These findings represent the first evidence that chondroitin sulfates, in general, participate in the process of neurosphere formation in vertebrates and imply a prominent function for the 473HD epitope. The mechanism involved, however, is presently unknown, although we tend to exclude apoptosis because the number of TUNEL-positive cells was the same in ChABC-treated and parallel control cultures (data not shown).

\section{Discussion}

In the present study, we show that the particular chondroitin sulfate epitope(s) recognized by the mAb 473HD (Faissner et al., 1994 ) is surface expressed on actively cycling radial glia in germinal zones during forebrain development as well as on multipotent neural stem/progenitor cells derived from the adult SVZ. We believe that our results are highly significant because (1) next to the LeX-type carbohydrate, the $473 \mathrm{HD}$ epitope represents the 
second known surface-expressed cue of radial glia with stem cell-like properties; (2) its structure is highly conserved, because the antibody works in mammals, birds, and amphibians alike and hence might have a wide range of potential applications; and (3) potential functions of chondroitinsulfates for NSC biology had not been reported previously. We developed immunoisolation protocols based on a $\mathrm{mAb}$ that can be used for the enrichment of the $473 \mathrm{HD}$-positive cell population from embryonic and adult forebrain. When challenged in different cell culture paradigms, $\sim 20 \%$ of the $473 \mathrm{HD}$ epitopeexpressing cells behaved as NSCs as defined by the neurosphere assay, and $80 \%$ generated immature neurons. 473HDpositive cells were also detectable in both embryonic and adult neurospheres. When enriched from neurospheres by immunoselection, the 473HD-positive cells displayed properties comparable to those derived from primary tissues. We conclude that the $\mathrm{mAb} 473 \mathrm{HD}$ identifies a population of neural stem/progenitor cells in the forebrain and reveals the functional relevance of defined chondroitin sulfate structures on the cell surface of these neural progenitor cells.

The 473HD epitope is surface expressed on actively cycling neural progenitor cells in germinal layers of the forebrain during development and in the adult neurogenic stem cell niche

The staining pattern of the 473HD epitope was associated with actively cycling BrdU-positive cells in the germinal layers of the forebrain with a pronounced expression of the epitope on radially oriented processes, suggestive of radial glia cells. The presence on radial glia was confirmed by marker analysis (e.g., BLBP, RC2, and GLAST) and after an immunopanning protocol was developed that allowed for the enrichment of $473 \mathrm{HD}$-positive cells to $>90 \%$. A similar degree of purity was obtained when the mAb 473HD was used for the magnetic beadbased system provided by EasySep. This compares well with other purification protocols that aimed at the isolation of retinal ganglion cells, radial glia, or adult NSCs (Barres et al., 1992; Malatesta et al., 2000; Capela and Temple, 2002). During forebrain development, the proportion of 473HD-positive cells declined from $15 \%$ at $\mathrm{E} 13$ to $7 \%$ at E18, which fits well the predicted behavior for any neural precursor population because, as development proceeds, an increasing fraction of progenitors is expected to leave the cell cycle and to become postmitotic. Considering this assertion and the coexpression of BLBP, it seems reasonable to assume that the $473 \mathrm{HD}$-positive cells represent neurogenic radial glia cells during embryonic forebrain development, in accordance with a recent fate-map analysis using BLBP-cre mice that scored most forebrain neurons (Anthony et al., 2004). Our findings also imply that the $473 \mathrm{HD}$ epitope is not associated with NG2-expressing multipotent NSCs (Aguirre et al., 2004). The $473 \mathrm{HD}$ epitope is also present in the adult NSC niches, as described previously for the SVZ (Gates et al., 1995). Here, we ex-
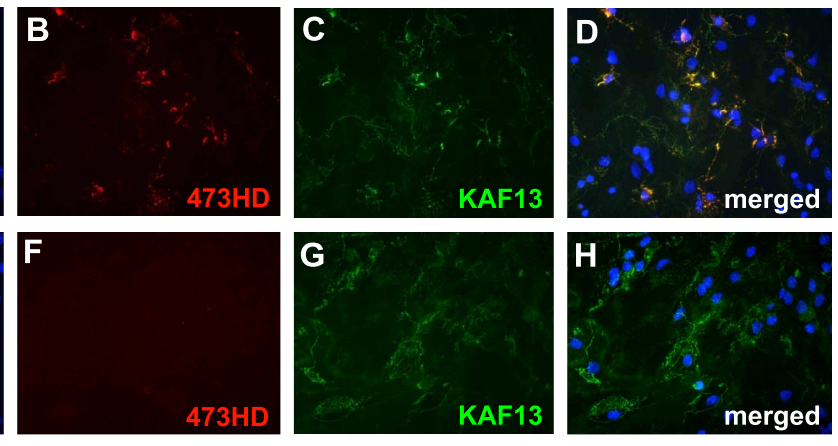

(1)

erged

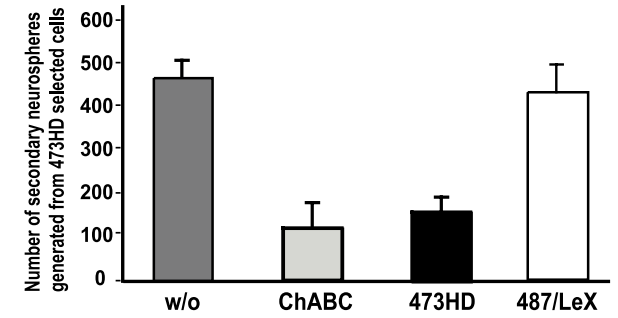

GE

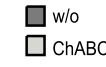

w/o

Figure 7. Interference with CS-GAGs including the 473HD epitope reveals a requirement for these carbohydrate structures in neurosphere formation. $\boldsymbol{A}-\boldsymbol{H}$, Photomicrographs of double-immunofluorescence stainings using the antibodies $473 \mathrm{HD}$ (red) and of the GAG-lyase ChABC on a laminin substrate. In control cultures, 473HD-positive cells are present $(\boldsymbol{B})$ and colocalize with KAF13

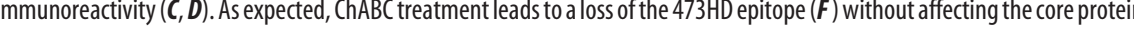

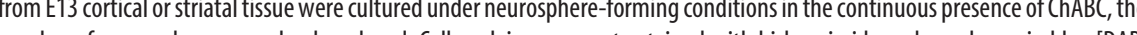
( 6 -diamidino-2-phenylindole)] $I$, The capacity to form neurospheres was threefold reduced for 473HD-positive cells derived that the addition of the 487/LeX isotype control antibody did not significantly alter the number of neurospheres. All data are least three independent experiments. Scale bar: (in $\boldsymbol{A}) \boldsymbol{A}-\boldsymbol{H}, 50 \mu \mathrm{m}$.

tend this observation by showing an extensive colocalization of the 473HD epitope with the adult NSC marker LeX (Capela and Temple, 2002) after immunopanning of 473HD-positive cells from the adult SVZ. We have shown previously that phosphacan besides $473 \mathrm{HD}$ also carries the LeX epitope (Garwood et al., 1999), and thus it seems possible that both epitopes are at least colocalized in part on neural progenitor cells and might contribute to the NSC niche. Similar to observations with the fluorescence-activated cell-sorted LeX-positive SVZ cells (Capela and Temple, 2002), the 473HD epitope was found expressed on BrdU-incorporating, possibly C-type transient, amplifying cells, $\beta$ III-tubulin- and PSA-NCAM-positive A-type neuroblasts, and only a subpopulation of GFAP-expressing SVZ cells. Interestingly, the GFAP- and 473HD-positive cells revealed morphologies similar to those described for stem cell astrocytes in the SVZ (Doetsch et al., 1999) and subgranular layer (Seri et al., 2001). Because the LeX and 473HD epitopes did not fully overlap, a more detailed investigation might allow for a finer molecular categorization of different neural progenitor substages in the SVZ, as has been achieved for adult hippocampal neurogenesis (Kempermann et al., 2004).

\section{Cell biology of forebrain-derived, immunoselected 473HD-positive cells}

The characterization of $473 \mathrm{HD}$-positive cells as neurogenic radial glia is consistent with $80 \%$ of the cells differentiating into imma- 
ture neurons. It is remarkable that the fraction of $473 \mathrm{HD}$-positive cells that engaged into the neuronal differentiation pathway never exceeded an $80 \%$ plateau, even after longer culture periods. This observation raises the question to which cell category the residual 20\% 473HD-positive cells belong. This latter population corresponds to 3 and $1.4 \%$ of the total number of cells obtained from the forebrain at E13 and E18, respectively. This one-fifth of the immunoselected 473HD-positive cell population gave rise to neurospheres that were able to self-renew and generated the expected numbers of neurons, astrocytes, and oligodendrocytes under differentiation conditions. Notably, these numbers are reminiscent of those reported for NSCs at comparable stages of development (Temple, 2001). We hypothesize that the 473HD epitope is present on NSCs and their immediate progeny before the epitope becomes downregulated in differentiating forebrain neurons, which were not enriched by immunopanning with $\mathrm{mAb}$ $473 \mathrm{HD}$ at embryonic stages. In this scenario, 473HD-positive cells at different stages along their lineage would be isolated that behave differently in dependence of the cell biological assays used, because they reflect different progenitor cell stages that display slightly different growth and survival requirements. Thus, the different culture conditions would sustain only the neural progenitor cell fraction or the more lineage-progressed neurogenic radial glia cells, as observed in the present study. With regard to the efficiency of the procedure presented here, it is of interest to consider the enrichment of neurosphere-forming units using the mAb 473HD. At E13, the fraction of neurosphereforming cells detected in cell suspensions could be increased threefold, also because of the comparatively high prevalence of NSCs at this developmental stage. This ratio augmented to more than sixfold at E18, when the fraction of NSCs has already diminished in native tissues, and was similar in the cortex and striatum. This achievement compares well with analogous procedures (e.g., the use of antibodies to $\beta 1$ integrins) (Campos et al., 2004), in which a sixfold increase has been reported. This finding is corroborated by the fact that the immunodepleted 473HDnegative cell population is primarily devoid of neurosphereforming cells, which reflects a total 15 -fold enrichment of neural progenitor cells in the $473 \mathrm{HD}$-positive cell population. The remaining neurosphere-forming cells in the negative cell population may easily be explained by either contaminating 473HDpositive cells in the negative fraction or by a second 473HDnegative neurosphere-forming progenitor cell that would represent a minority of NSCs. Although the exact relationship between neurosphere-forming cells in vitro and neural progenitor cells in vivo remains to be fully established, the neurosphere assay is still the best cell culture model to assay NSC properties of putative neural progenitor cells.

\section{Core glycoproteins that express the 473HD epitope and relationship to other proteoglycans}

In the CNS, the $473 \mathrm{HD}$ epitope has originally been detected on the proteoglycan isoforms of the RPTP $\beta$ gene (Faissner et al., 1994; Garwood et al., 1999). Four different gene products are generated from this locus by alternative splicing (Garwood et al., 2003), but only phosphacan and RPTP $\beta$-long encompass the socalled intervening sequence, which harbors most, if not all, glycosaminoglycan attachment sites. For these reasons, only phosphacan and RPTP $\beta$-long are likely to bear the $473 \mathrm{HD}$ chondroitin sulfate epitope. The messages and the proteins of both RPTP $\beta$-long and phosphacan could be detected in E13 neurospheres cultured for $6 \mathrm{~d}$ (our unpublished observations). Thus, $473 \mathrm{HD}$-positive cells most probably expose the epitope on the large receptor form RPTP $\beta$-long, although alternative core proteins carrying the $473 \mathrm{HD}$ epitope have not been excluded. Consistent with this interpretation, the RPTP $\beta$ gene has surfaced in systematic screens based on the gene array technology that aimed at the characterization of "stemness"-related gene expression patterns in NSCs (Ramalho-Santos et al., 2002; D’Amour and Gage, 2003).

\section{Cell biological role of CS-GAGs on 473HD-positive cells}

Deglycanation of CS-GAGs in immunoselected 473HD-positive cells reduced their capacity to form neurospheres twofold to threefold even in the presence of heparin, suggesting an essential function for this class of carbohydrates in proliferating 473HDpositive neural progenitors. Moreover, the mAb 473HD specifically reduced neurosphere formation to a similar degree, which suggests that the $473 \mathrm{HD}$ epitope constitutes an important functional entity. In this context, it is interesting to note that the 473HD epitope overlaps with growth factor binding sites in defined chondroitin sulfate motifs, including some FGFs (Deepa et al., 2004). Also, a close vicinity to a binding motif for midkine/ pleiotrophin could recently be disclosed (Bao et al., 2005), and pleitrophin has been shown to be required for neural progenitor cell proliferation (Hienola et al., 2004). What might be the role of the $473 \mathrm{HD}$ epitope in the context of NSC biology? At present, we can only speculate about the mechanism, but as we could exclude apoptosis, it is plausible in light of the findings in C. elegans (Hwang et al., 2003) that CS-GAGs including the 473HD epitope are involved in the control of neural stem/progenitor proliferation.

\section{References}

Aguirre AA, Chittajallu R, Belachew S, Gallo V (2004) NG2-expressing cells in the subventricular zone are type C-like cells and contribute to interneuron generation in the postnatal hippocampus. J Cell Biol 165:575-589.

Alvarez-Buylla A, Lim DA (2004) For the long run: maintaining germinal niches in the adult brain. Neuron 41:683-686.

Alvarez-Buylla A, Garcia-Verdugo JM, Tramontin AD (2001) A unified hypothesis on the lineage of neural stem cells. Nat Rev Neurosci 2:287-293.

Anthony TE, Klein C, Fishell G, Heintz N (2004) Radial glia serve as neuronal progenitors in all regions of the central nervous system. Neuron 41:881-890.

Bao X, Mikami T, Yamada S, Faissner A, Muramatsu T, Sugahara K (2005) Heparin-binding growth factor, pleiotrophin, mediates neuritogenic activity of embryonic pig brain-derived chondroitin sulfate/dermatan sulfate hybrid chains. J Biol Chem 280:9180-9191.

Bard JL, Kaufman MH, Dubreuil C, Brune RM, Burger A, Baldock RA, Davidson DR (1998) An internet-accessible database of mouse developmental anatomy based on a systematic nomenclature. Mech Dev 74:111-120.

Barres BA, Hart IK, Coles HS, Burne JF, Voyvodic JT, Richardson WD, Raff MC (1992) Cell death and control of cell survival in the oligodendrocyte lineage. Cell 70:31-46.

Belachew S, Chittajallu R, Aguirre AA, Yuan X, Kirby M, Anderson S, Gallo V (2003) Postnatal NG2 proteoglycan-expressing progenitor cells are intrinsically multipotent and generate functional neurons. J Cell Biol 161:169-186.

Bradbury EJ, Moon LD, Popat RJ, King VR, Bennett GS, Patel PN, Fawcett JW, McMahon SB (2002) Chondroitinase ABC promotes functional recovery after spinal cord injury. Nature 416:636-640.

Braun N, Sevigny J, Mishra SK, Robson SC, Barth SW, Gerstberger R, Hammer K, Zimmermann H (2003) Expression of the ecto-ATPase NTPDase 2 in the germinal zones of the developing and adult rat brain. Eur J Neurosci 17:1355-1364.

Campos LS, Leone DP, Relvas JB, Brakebusch C, Fassler R, Suter U, FfrenchConstant C (2004) Betal integrins activate a MAPK signalling pathway in neural stem cells that contributes to their maintenance. Development 131:3433-3444.

Canoll PD, Petanceska S, Schlessinger J, Musacchio JM (1996) Three forms 
of RPTP- $\beta$ are differentially expressed during gliogenesis in the developing rat brain and during glial cell differentiation in culture. J Neurosci Res 44:199-215.

Capela A, Temple S (2002) LeX/ssea-1 is expressed by adult mouse CNS stem cells, identifying them as nonependymal. Neuron 35:865-875.

Chanas-Sacre G, Thiry M, Pirard S, Rogister B, Moonen G, Mbebi C, Verdiere-Sahuque M, Leprince P (2000) A 295-kDA intermediate filament-associated protein in radial glia and developing muscle cells in vivo and in vitro. Dev Dyn 219:514-525.

Clement AM, Nadanaka S, Masayama K, Mandl C, Sugahara K, Faissner A (1998) The DSD-1 carbohydrate epitope depends on sulfation, correlates with chondroitin sulfate D motifs, and is sufficient to promote neurite outgrowth. J Biol Chem 273:28444-28453.

D’Amour KA, Gage FH (2003) Genetic and functional differences between multipotent neural and pluripotent embryonic stem cells. Proc Natl Acad Sci USA 100 [Suppl 1]:11866-11872.

Deepa SS, Yamada S, Zako M, Goldberger O, Sugahara K (2004) Chondroitin sulfate chains on syndecan- 1 and syndecan- 4 from normal murine mammary gland epithelial cells are structurally and functionally distinct, and co-operate with heparan sulfate chains to bind growth factors: a novel function to control binding of midkine, pleiotrophin and basic fibroblast growth factor. J Biol Chem 279:37368-37376.

Diers-Fenger M, Kirchhoff F, Kettenmann H, Levine JM, Trotter J (2001) AN2/NG2 protein-expressing glial progenitor cells in the murine CNS: isolation, differentiation, and association with radial glia. Glia $34: 213-228$

Dobbertin A, Rhodes KE, Garwood J, Properzi F, Heck N, Rogers JH, Fawcett JW, Faissner A (2003) Regulation of RPTPbeta/phosphacan expression and glycosaminoglycan epitopes in injured brain and cytokine-treated glia. Mol Cell Neurosci 24:951-971.

Doetsch F (2003) The glial identity of neural stem cells. Nat Neurosci 6:1127-1134.

Doetsch F, Caille I, Lim DA, Garcia-Verdugo JM, Alvarez-Buylla A (1999) Subventricular zone astrocytes are neural stem cells in the adult mammalian brain. Cell 97:703-716.

Doetsch F, Petreanu L, Caille I, Garcia-Verdugo JM, Alvarez-Buylla A (2002) EGF converts transit-amplifying neurogenic precursors in the adult brain into multipotent stem cells. Neuron 36:1021-1034.

Engel M, Maurel P, Margolis RU, Margolis RK (1996) Chondroitin sulfate proteoglycans in the developing central nervous system. I. cellular sites of synthesis of neurocan and phosphacan. J Comp Neurol 366:34-43.

Faissner A, Clement A, Lochter A, Streit A, Mandl C, Schachner M (1994) Isolation of a neural chondroitin sulfate proteoglycan with neurite outgrowth promoting properties. J Cell Biol 126:783-799.

Feng L, Hatten ME, Heintz N (1994) Brain lipid-binding protein (BLBP): a novel signaling system in the developing mammalian CNS. Neuron 12:895-908.

Gage FH (2000) Mammalian neural stem cells. Science 287:1433-1438.

Garcion E, Halilagic A, Faissner A, Ffrench-Constant C (2004) Generation of an environmental niche for neural stem cell development by the extracellular matrix molecule tenascin C. Development 131:3423-3432.

Garwood J, Schnadelbach O, Clement A, Schutte K, Bach A, Faissner A (1999) DSD-1-proteoglycan is the mouse homolog of phosphacan and displays opposing effects on neurite outgrowth dependent on neuronal lineage. J Neurosci 19:3888-3899.

Garwood J, Heck N, Reichardt F, Faissner A (2003) Phosphacan short isoform, a novel non-proteoglycan variant of phosphacan/receptor protein tyrosine phosphatase-beta, interacts with neuronal receptors and promotes neurite outgrowth. J Biol Chem 278:24164-24173.

Gates MA, Thomas LB, Howard EM, Laywell ED, Sajin B, Faissner A, Gotz B, Silver J, Steindler DA (1995) Cell and molecular analysis of the developing and adult mouse subventricular zone of the cerebral hemispheres. J Comp Neurol 361:249-266.

Hartfuss E, Galli R, Heins N, Gotz M (2001) Characterization of CNS precursor subtypes and radial glia. Dev Biol 229:15-30.

Hienola A, Pekkanen M, Raulo E, Vanttola P, Rauvala H (2004) HB-GAM inhibits proliferation and enhances differentiation of neural stem cells. Mol Cell Neurosci 26:75-88.

Horner PJ, Thallmair M, Gage FH (2002) Defining the NG2-expressing cell of the adult CNS. J Neurocytol 31:469-480.
Hwang HY, Olson SK, Esko JD, Horvitz HR (2003) Caenorhabditis elegans early embryogenesis and vulval morphogenesis require chondroitin biosynthesis. Nature 423:439-443.

Ito Y, Hikino M, Yajima Y, Mikami T, Sirko S, von Holst A, Faissner A, Fukui S, Sugahara K (2005) Structural characterization of the epitopes of the monoclonal antibodies 473HD, CS-56, and MO-225 specific for chondroitin sulfate D-type using the oligosaccharide library. Glycobiology 15:593-603.

Kempermann G, Jessberger S, Steiner B, Kronenberg G (2004) Milestones of neuronal development in the adult hippocampus. Trends Neurosci 27:447-452.

Kim M, Morshead CM (2003) Distinct populations of forebrain neural stem and progenitor cells can be isolated using side-population analysis. J Neurosci 23:10703-10709.

Malatesta P, Hartfuss E, Gotz M (2000) Isolation of radial glial cells by fluorescent-activated cell sorting reveals a neuronal lineage. Development 127:5253-5263.

Malatesta P, Hack MA, Hartfuss E, Kettenmann H, Klinkert W, Kirchhoff F, Gotz M (2003) Neuronal or glial progeny: regional differences in radial glia fate. Neuron 37:751-764.

Miyata T, Kawaguchi A, Okano H, Ogawa M (2001) Asymmetric inheritance of radial glial fibers by cortical neurons. Neuron 31:727-741.

Mizuguchi S, Uyama T, Kitagawa H, Nomura KH, Dejima K, Gengyo-Ando K, Mitani S, Sugahara K, Nomura K (2003) Chondroitin proteoglycans are involved in cell division of Caenorhabditis elegans. Nature 423:443-448.

Noctor SC, Flint AC, Weissman TA, Dammerman RS, Kriegstein AR (2001) Neurons derived from radial glial cells establish radial units in neocortex. Nature 409:714-720.

Noctor SC, Flint AC, Weissman TA, Wong WS, Clinton BK, Kriegstein AR (2002) Dividing precursor cells of the embryonic cortical ventricular zone have morphological and molecular characteristics of radial glia. J Neurosci 22:3161-3173.

Ohyama K, Ikeda E, Kawamura K, Maeda N, Noda M (2004) Receptor-like protein tyrosine phosphatase zeta/RPTP beta is expressed on tangentially aligned neurons in early mouse neocortex. Brain Res Dev Brain Res 148:121-127.

Ramalho-Santos M, Yoon S, Matsuzaki Y, Mulligan RC, Melton DA (2002) "Stemness": transcriptional profiling of embryonic and adult stem cells. Science 298:597-600.

Rietze RL, Valcanis H, Brooker GF, Thomas T, Voss AK, Bartlett PF (2001) Purification of a pluripotent neural stem cell from the adult mouse brain. Nature 412:736-739.

Rougon G, Dubois C, Buckley N, Magnani JL, Zollinger W (1986) A monoclonal antibody against meningococcus group B polysaccharides distinguishes embryonic from adult N-CAM. J Cell Biol 103:2429-2437.

Seri B, Garcia-Verdugo JM, McEwen BS, Alvarez-Buylla A (2001) Astrocytes give rise to new neurons in the adult mammalian hippocampus. J Neurosci 21:7153-7160.

Shibata T, Yamada K, Watanabe M, Ikenaka K, Wada K, Tanaka K, Inoue Y (1997) Glutamate transporter GLAST is expressed in the radial glia-astrocyte lineage of developing mouse spinal cord. J Neurosci 17:9212-9219.

Sidman RL, Rakic P (1973) Neuronal migration, with special reference to developing human brain: a review. Brain Res 62:1-35.

Sommer I, Schachner M (1981) Monoclonal antibodies (O1 to O4) to oligodendrocyte cell surfaces: an immunocytological study in the central nervous system. Dev Biol 83:311-327.

Streit A, Yuen CT, Loveless RW, Lawson AM, Finne J, Schmitz B, Feizi T, Stern CD (1996) The Le(x) carbohydrate sequence is recognized by antibody to L5, a functional antigen in early neural development. J Neurochem 66:834-844.

Temple S (2001) The development of neural stem cells. Nature 414:112-117.

Tramontin AD, Garcia-Verdugo JM, Lim DA, Alvarez-Buylla A (2003) Postnatal development of radial glia and the ventricular zone (VZ): a continuum of the neural stem cell compartment. Cereb Cortex 13:580-587.

von Holst A, Rohrer H (1998) Culture of avian sympathetic neurons. Curr Top Dev Biol 36:161-182.

Wodarz A, Huttner WB (2003) Asymmetric cell division during neurogenesis in Drosophila and vertebrates. Mech Dev 120:1297-1309. 